\title{
Investigations in the boletes (Boletaceae) of southeastern USA: four novel species and three novel combinations
}

\author{
Farid $\mathrm{A}^{1}$, Bessette $\mathrm{AE}^{2}$, Bessette $\mathrm{AR}^{2}$, Bolin $\mathrm{JA}^{3}$, Kudzma $\mathrm{LV}^{4}$, Franck $\mathrm{AR}^{5}$ and \\ Garey $\mathbf{J R}^{1^{*}}$
}

${ }^{1}$ Herbarium, Department of Cell, Molecular, and Microbiology, University of South Florida, Tampa, Florida 33620

${ }^{2} 3109$ William Penn Ct, Burlington, NC 27215

${ }^{3} 7340$ Viale Sonata, Lake Worth, Florida 33467

${ }^{4} 37$ Maple Ave., Annandale, NJ 08801

${ }^{5}$ University of Florida Herbarium, Florida Museum of Natural History, Gainesville, Florida 32611

Farid A, Bessette AE, Bessette AR, Bolin JA, Kudzma LV, Franck AR, Garey JR 2021 Investigations in the boletes (Boletaceae) of southeastern USA: four novel species, and three novel combinations. Mycosphere 12(1), 1038-1076, Doi 10.5943/mycosphere/12/1/12

\begin{abstract}
The Boletaceae is the largest family of fleshy fungi in the Boletales. Despite the extensive history of work in the Boletaceae in North America, novel species and genera are continually being described. Multigene molecular phylogenetic analyses of five loci were combined with thorough morphological studies to investigate the taxonomy of several boletes from the southeastern USA. Based on our results, we describe four new species: Aureoboletus pseudoauriporus, Cyanoboletus bessettei, Hemileccinum floridanum, and Xerocomellus bolinii. We also propose three combinations to reflect the results of our molecular analyses: Cyanoboletus cyaneitinctus comb. nov., a bolete that is widespread across the eastern USA, C. cyaneitinctus f. reticulatus, and Lanmaoa sublurida, a rarely-documented bolete that is so far known only from Florida.
\end{abstract}

Keywords - Boletales - ectomycorrhizal - phylogeny

\section{Introduction}

The boletes of the southeastern USA are diverse but poorly studied. Perhaps the first taxonomic work on the southeastern boletes began with Thomas Walter's (Walter 1788) Boletus dimidiatus, nom. illeg. Several more southeastern boletes were described by von Schweinitz (1822) and Berkeley \& Curtis (1853). Peck and Frost were both prolific with bolete studies in the late 1800s (Halling 1983, Both \& Ortiz-Santana 2010). Murrill (1909) published the first monograph of the boletes of North America, although after its publication, he described many more species of boletes (Halling 1986), especially from Florida (Weber 1961, Halling 1986). Coker \& Beers (1943) published a monograph of the boletes of North Carolina. Rolf Singer published a monograph on the boletes of Florida (Singer 1945a, b, 1947), which treated species common to the southeastern USA, endemic to Florida, and extralimital species from around the globe. Later, Murrill (1948) published a summation of Florida boletes, one of the last broad treatments of the boletes of the region. Other works broadly focused on boletes in the southeastern USA included Thiers (1963) and Grand (1970a, b, c). Both (1993) published a compendium of all boletes described in North America, providing diagnostic features as well as taxonomic notes on each species. Despite the extensive history and monographic treatments, novel species of boletes from the southeastern USA are continually being described 
(Singer \& Williams 1992, Baroni 1998, Baroni et al. 1998, Ortiz-Santana et al. 2009, 2016, Frank et al. 2017, Crous et al. 2019, Farid et al. 2020).

Molecular phylogenetic analyses have redefined our understanding of the boletes. Once considered to consist of only a few genera, the Boletaceae has now increased to over 70 genera (Nuhn et al. 2013, Wu et al. 2014, 2016). In part, this expansion is due to the recognition of sequestrate (Yang et al. 2006, Smith et al. 2015, Castellano et al. 2016, Vadthanarat et al. 2018, Wu et al. 2018) and new lamellate (Farid et al. 2018, Zhang \& Li 2018) genera. This increase of genera is also due to molecular phylogenetic analyses allowing taxonomists to better recognize synapomorphies, as many of the traditional characters used to classify the boletes were homoplasic. The broad relationships between genera are also better understood with analyses of molecular data. An analysis of 290 operational taxonomic units (OTUs) across 59 genus-level clades by Wu et al. (2014) also revealed six subfamily-level recognitions (Xerocomoideae, Leccinoideae, Boletoideae, Austroboletoideae, Zangioideae, and Chalcioporoideae), although some genera did not resolve to any of the known subfamilies (Solioccasus Trappe, Osmundson, Manfr. Binder, Castellano \& Halling, Bothia Halling, T.J. Baroni \& Manfr. Binder, Gymnogaster J.W. Cribb, Baorangia G. Wu \& Zhu L. Yang, and Pseudoboletus Šutara), including one large grouping of genera (the Pulveroboletus group). While much of the genus-level taxonomy has been explored in the Boletoideae, Xerocomoideae, and the Pulveroboletus group (Murrill 1909, Halling et al. 2012, Vizzini 2014, Zhao et al. 2014, Gelardi et al. 2015, Wu et al. 2016, Vadthanarat et al. 2019), many species-level taxa are still being described.

Boletes serve vital ecological roles as ectomycorrhizae of the primary forest trees (Quercus and Pinus) of the southeastern USA, yet the extent of their diversity in this region is largely unknown. The aim of this paper is to update our understanding of boletes in southeastern North America, through multigene phylogenetic analyses. The name Boletus cyaneitinctus is resurrected for a species closely related to Cyanoboletus pulverulentus (Opat.) Gelardi, Vizzini \& Simonini. This paper provides the first phylogenetic analyses of a rarely documented bolete, Suillellus subluridus Murrill, which is transferred to Lanmaoa. We also describe four novel species, including one of Xerocomellus, an uncommon species of Cyanoboletus, a species that resembles Hemileccinum subglabripes (Peck) Halling, and one that resembles Aureoboletus auriporus (Peck) Pouzar. We also generated protein-coding sequences from the epitype of Pulchroboletus rubricitrinus, as well as from specimens of western Xerocomellus. Finally, we generated sequences from an herbarium specimen of Exsudoporus floridanus from Florida and discuss the generic concepts of Exsudoporus and Butyriboletus.

\section{Materials \& Methods}

\section{Sampling and morphological studies}

Specimens were collected in situ between 2015-2020 and deposited at the University of South Florida Herbarium (USF). Additional collections were obtained on loan from Florida Museum of Natural History (FLAS) for study. Macroscopic descriptions were made using fresh basidiomes. Micromorphological features were observed with a phase contrast microscope (AmScope, Irvine, CA, USA). Distilled $\mathrm{H}_{2} \mathrm{O}$, lactoglycerol, $\mathrm{KOH}$, and Phloxine B were used to rehydrate and stain sections (Singer 1986). Measurements were made at $1000 \times$ with a calibrated ocular micrometer in Piximètre 5.9 R 1532 (http://piximetre.fr). Basidiospore dimensions are reported as length by width, with each measurement reported as the minimum, the average minus the standard deviation, the average plus the standard deviation, and the maximum. Spore dimensions are followed by the number of spores counted, $\mathrm{N}$, and the average quotient mean, $\mathrm{Q}$, where $\mathrm{Q}$ is the average length divided by the average width. Scanning Electron Microscopy (SEM) was performed at the Electron Microscopy Core Facility at the University of South Florida on an Aquila Hybrid Scanning Electron Microscope (Topcon, Tokyo, Japan).

\section{DNA Extraction, PCR amplification, and sequencing}

Genomic DNA was isolated as described in Farid et al. (2017). A subset of the samples was 
extracted using the NucleoSpin Plant II Kit (Macherey-Nagel Inc. Bethlehem, Pennsylvania, USA). Portions of five gene regions were targeted for phylogenetic analysis: nuc rDNA internal transcribed spacer ITS1-5.8S-ITS (ITS), nuc 28S rDNA (28S), RNA polymerase II subunit 1 (RPB1), RNA polymerase II subunit 2 (RPB2), and translation elongation factor 1-alpha (TEF1) were amplified according to Farid et al. (2019). The primer pair ITS1-F/ITS4 (White et al. 1990). Gardes \& Bruns 1993) were used to amplify ITS, LR0R/LR7 (Vilgalys \& Hester 1990) for 28S. The bolete-specific primer pairs EF1-BF1/EF1-B-R, RPB1-B-F/RPB1-B-R, and RPB2-B-F1/RPB2-B-R (Wu et al. 2014 ) were used to amplify $T E F 1, R P B 1$, and $R P B 2$, respectively. Crude PCR product was purified and sequenced at the DNA laboratory at Arizona State University with a 3730 DNA Analyzer (applied Biosystems, Carlsbad, CA, USA) using the same PCR primers for amplification, and additionally the internal 28S primers LR5 and LR3R were used (Vilgalys \& Hester 1990).

A subset of samples (JAB 95 and JAB 80) was obtained using a nested PCR method. First, the primer pair gRPB1-Af/fRPB1-Cr (Matheny et al. 2002) were used to amplify a portion of the RPB1 gene; PCR products were then diluted in nanoPure $\mathrm{H}_{2} \mathrm{O}$ in a 1:100 ratio used in a second hemi-nested PCR using one of the original primers gRPB1-Af or fRPB1-Cr paired with an internal primer chosen from either RPB1-B-F or RPB1-B-R or one of two novel Boletales specific primers (Table 1).

Table 1 Primer design Boletales-specific $R P B 1$ primers

\begin{tabular}{ll}
\hline Primer name & Sequence $\left(5^{\prime} \rightarrow \mathbf{3}^{\prime}\right.$ ) \\
\hline RPB1mexF1bol & CGRCATGTYCGCGATCC \\
RPB1mexR2bol & GGWTCRTCAGYTTCGCA \\
\hline
\end{tabular}

\section{Alignments, model selection, and phylogenetic analyses}

A multi-locus phylogeny consisting of ITS, 28S, RPB1, RPB2, and TEF1. Alignments of each locus were made in R (R Core Team 2017) using MAFFT v. 7.471; alignments of rDNA used the predicted secondary structure to improve the alignment. Gblocks v. 0.91b (Katoh \& Standley 2013) was used to remove ambiguous regions of the resultant alignments to improve phylogenetic inference. Models were selected for each locus using jModelTest 2.1.10 (Guindon \& Gascuel 2003, Darriba et al. 2012). Bayesian information criterion models were selected for each partition, though we report all the models selected (Table 2). The resultant alignments were combined in Sequence Matrix (http://www.ggvaidya.com/taxondna/), with taxa missing target loci encoded as missing data (Felsenstein 2004). Seventeen genera from the Boletaceae were included in the phylogenetic analyses (Fig. 1): Aureoboletus Pouzar, Hemileccinum Šutara, Pulchroboletus Gelardi, Vizzini \& Simonini, Heimioporus E. Horak, Alessioporus Gelardi, Vizzini \& Simonini, Xerocomellus Šutara, Nigroboletus Gelardi, Vizzini, E. Horak, T.H. Li \& Ming Zhang, Hortiboletus Simonini, Vizzini \& Gelardi, Boletus L., Baorangia G. Wu \& Zhu L. Yang, Cyanoboletus Gelardi, Vizzini \& Simonini, Lanmaoa G. Wu \& Zhu L. Yang, Butyriboletus D. Arora \& J.L. Frank, Suillellus Murrill, Gymnogaster J.W. Cribb, Chalciporus Bataille, and Buchwaldoboletus Pilát.

Phylogenetic analyses were conducted using the CIPRES Gateway server V3.3 (Miller et al. 2010). Maximum likelihood (ML) was conducted with RAXML-HPC 8.2.10 (Stamatakis 2014) using 1000 non-parametric bootstrap replicates (BS) and a partitioned model. Bayesian inference (BI) was conducted with MrBayes 3.2.6 on XSEDE platform of the CIPRES Science Gateway server (Ronquist et al. 2012). Four Markov chain Monte Carlo simulations were run for ten million generations, sampling trees every thousand generations. Chain convergence was determined using Tracer V1.6 (Rambaut et al. 2018). The first $25 \%$ were discarded as burn-in, and a majority rule consensus tree was computed to obtain estimates for Bayesian posterior probabilities (BPP). BI trees were visualized in Figtree (Rambaut 2007) and exported into Inkscape, where bootstrap values were added to node labels. BPP above 0.90 and bootstrap values above $70 \%$ were reported. Alignment and phylogenetic trees were uploaded to http://www.treebase.org/ (submission ID 27951). 
Table 2 Models selected for each locus using different model strategies in jModelTest 2.1.10. Abbreviations: AICc $=$ Akaike information criterion. $\mathrm{BIC}=$ Bayesian information criterion. $\mathrm{DT}=$ Decision theory. GTR = Generalized time reversible model. HKY = Hasegawa, Kishino and Yano 1985 model. K80 = Kimura\&\#39; s two parameter model. SYM = Symmetrical model. I = Invariant. $\mathrm{G}=$ Gamma

\begin{tabular}{|c|c|c|c|c|c|}
\hline \multirow[t]{2}{*}{ Model Strategy } & \multicolumn{5}{|c|}{ Locus } \\
\hline & ITS & $28 S$ & $R P B 1$ & $R P B 2$ & TEF \\
\hline AICc & $\mathrm{GTR}+\mathrm{I}+\mathrm{G}$ & $\mathrm{GTR}+\mathrm{I}+\mathrm{G}$ & $\mathrm{HKY}+\mathrm{I}+\mathrm{G}$ & $\mathrm{SYM}+\mathrm{I}+\mathrm{G}$ & $\mathrm{HKY}+\mathrm{I}+\mathrm{G}$ \\
\hline BIC & $\mathrm{GTR}+\mathrm{I}+\mathrm{G}$ & $\mathrm{GTR}+\mathrm{I}+\mathrm{G}$ & $\mathrm{K} 80+\mathrm{I}+\mathrm{G}$ & $\mathrm{K} 80+\mathrm{I}+\mathrm{G}$ & $\mathrm{HKY}+\mathrm{I}+\mathrm{G}$ \\
\hline DT & $\mathrm{HKY}+\mathrm{I}+\mathrm{G}$ & $\mathrm{GTR}+\mathrm{I}+\mathrm{G}$ & $\mathrm{K} 80+\mathrm{I}+\mathrm{G}$ & $\mathrm{K} 80+\mathrm{I}+\mathrm{G}$ & $\mathrm{HKY}+\mathrm{I}+\mathrm{G}$ \\
\hline
\end{tabular}

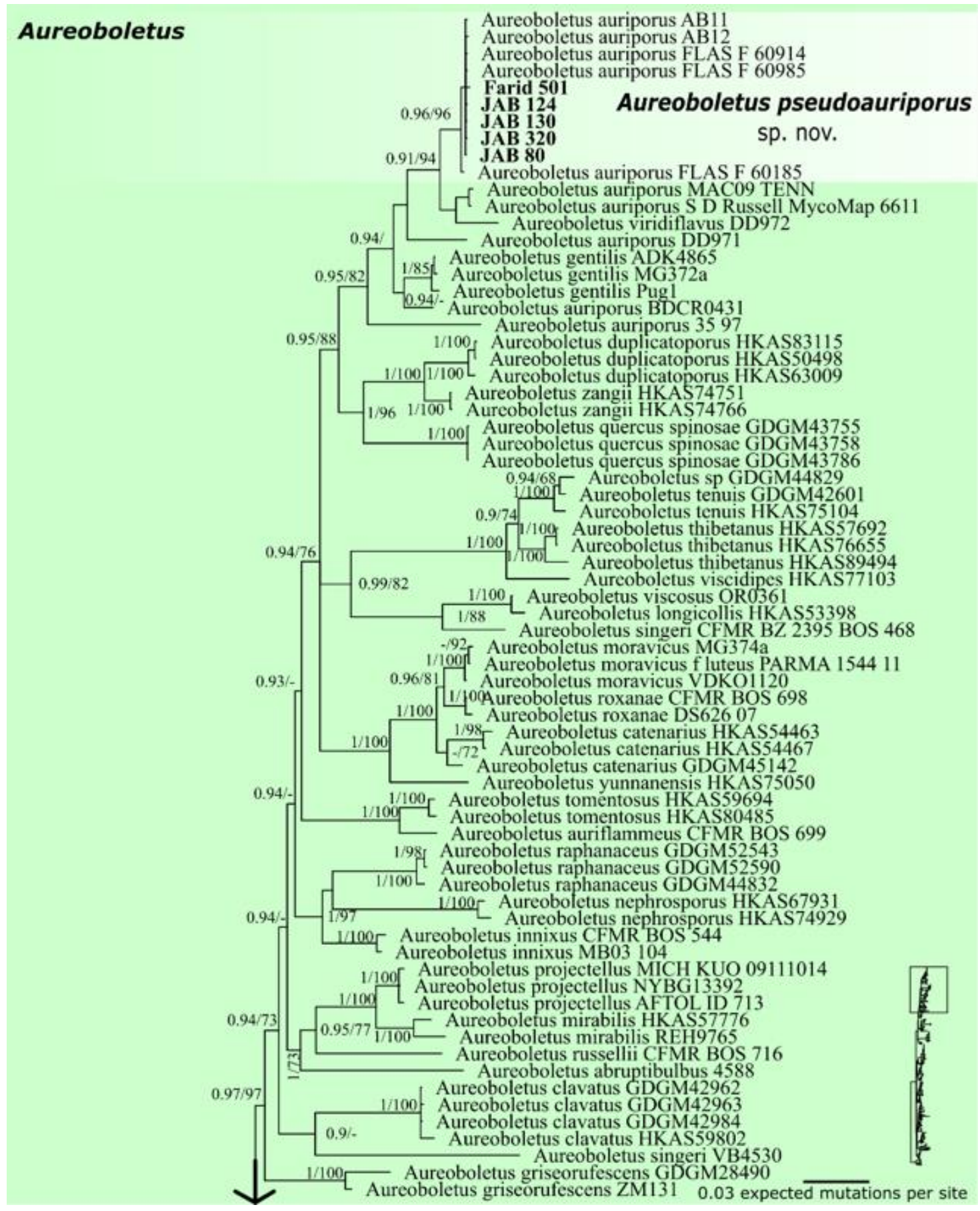

Figure 1 - Phylogram generated from MrBayes based on ITS, 28S, RPB1, RPB2, and TEF1 sequence data. Nodes labeled with PP $(\geq 0.90)$ followed by bootstrap replicate support $(\geq 70)$. Colors represent 
distinct genera. Specimens with molecular data generated in this study are bolded. Inset phylogeny depicts portion of phylogeny shown in figure.

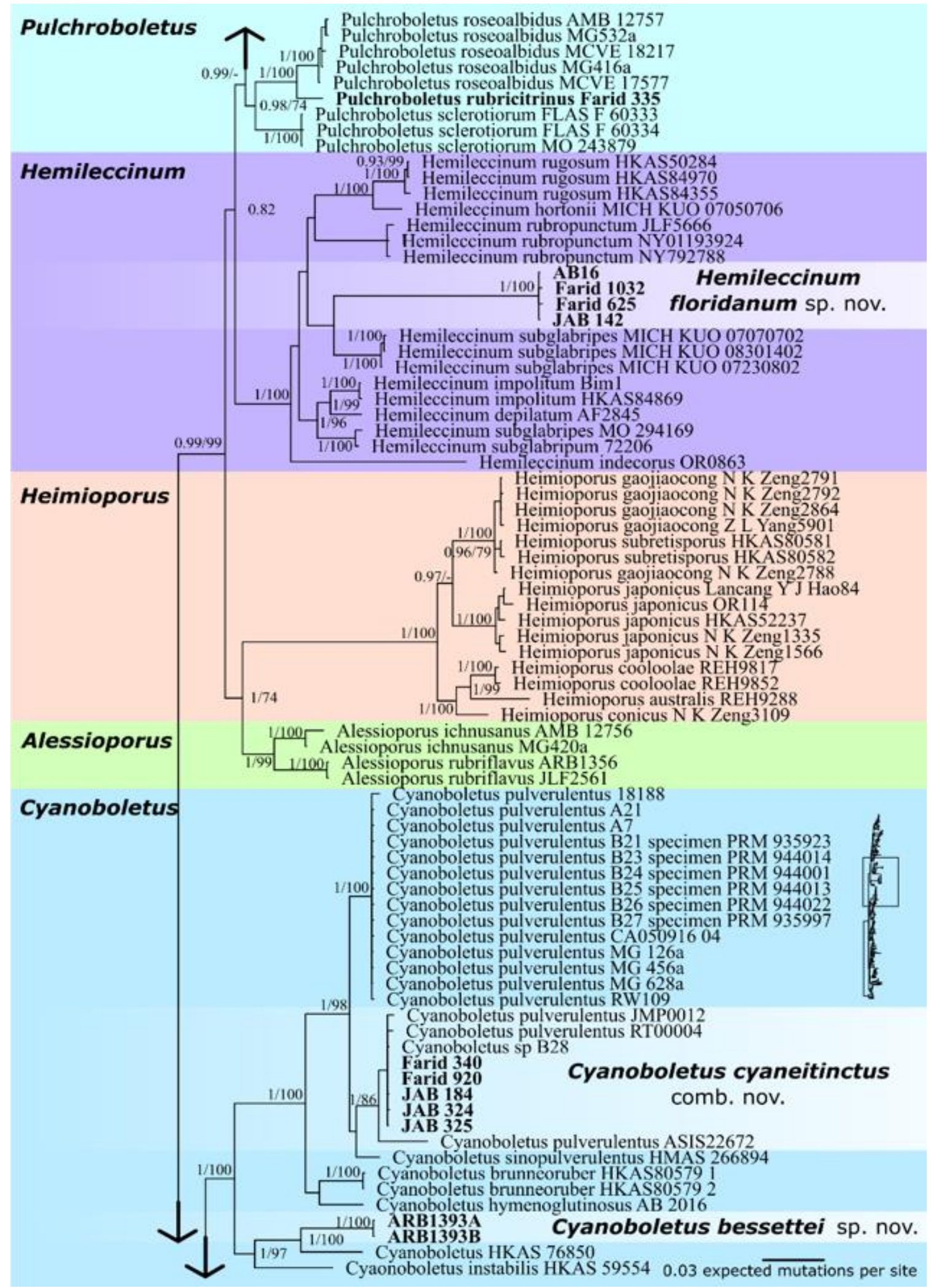

Figure 1 - Continued. 


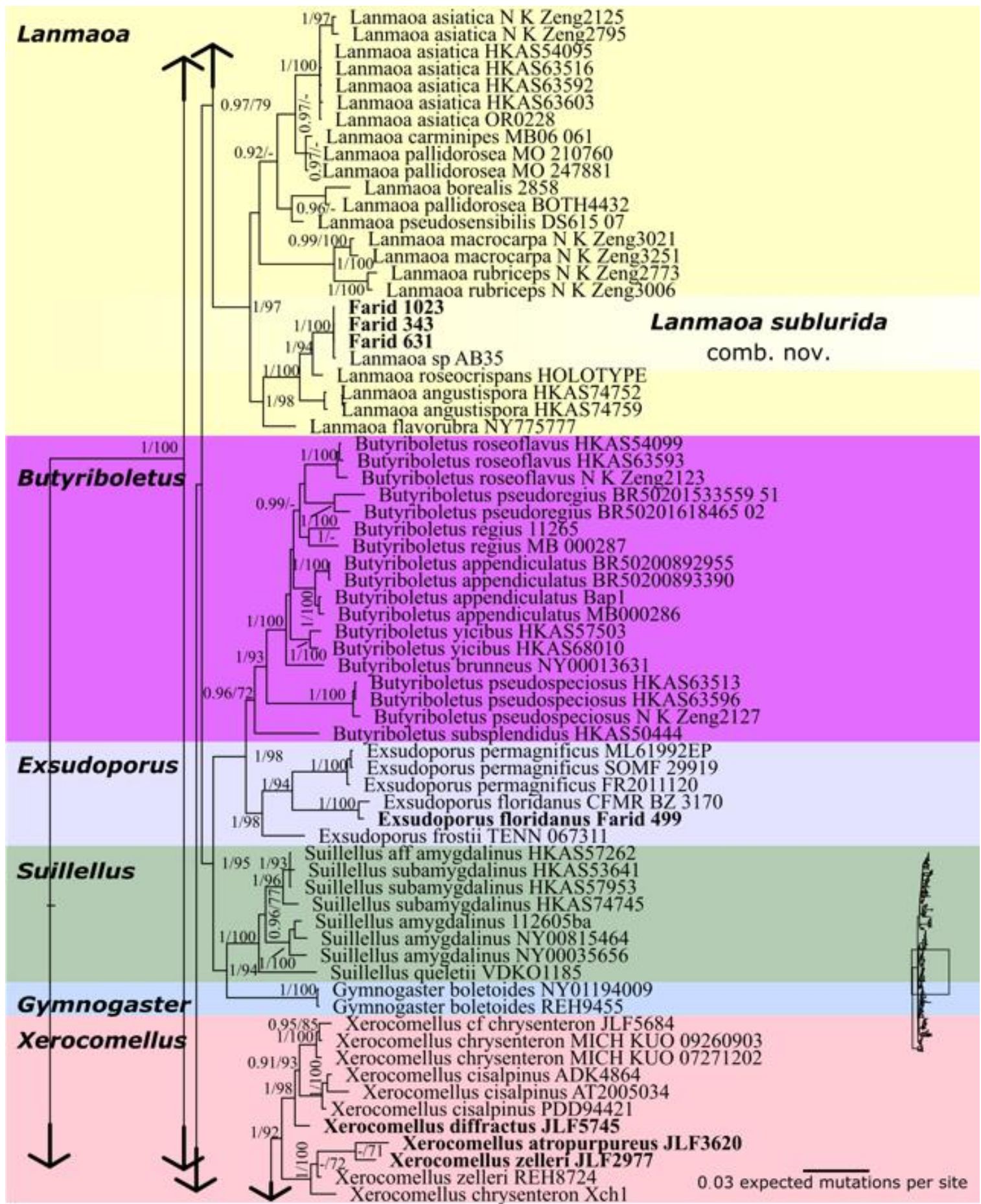

Figure 1 - Continued. 


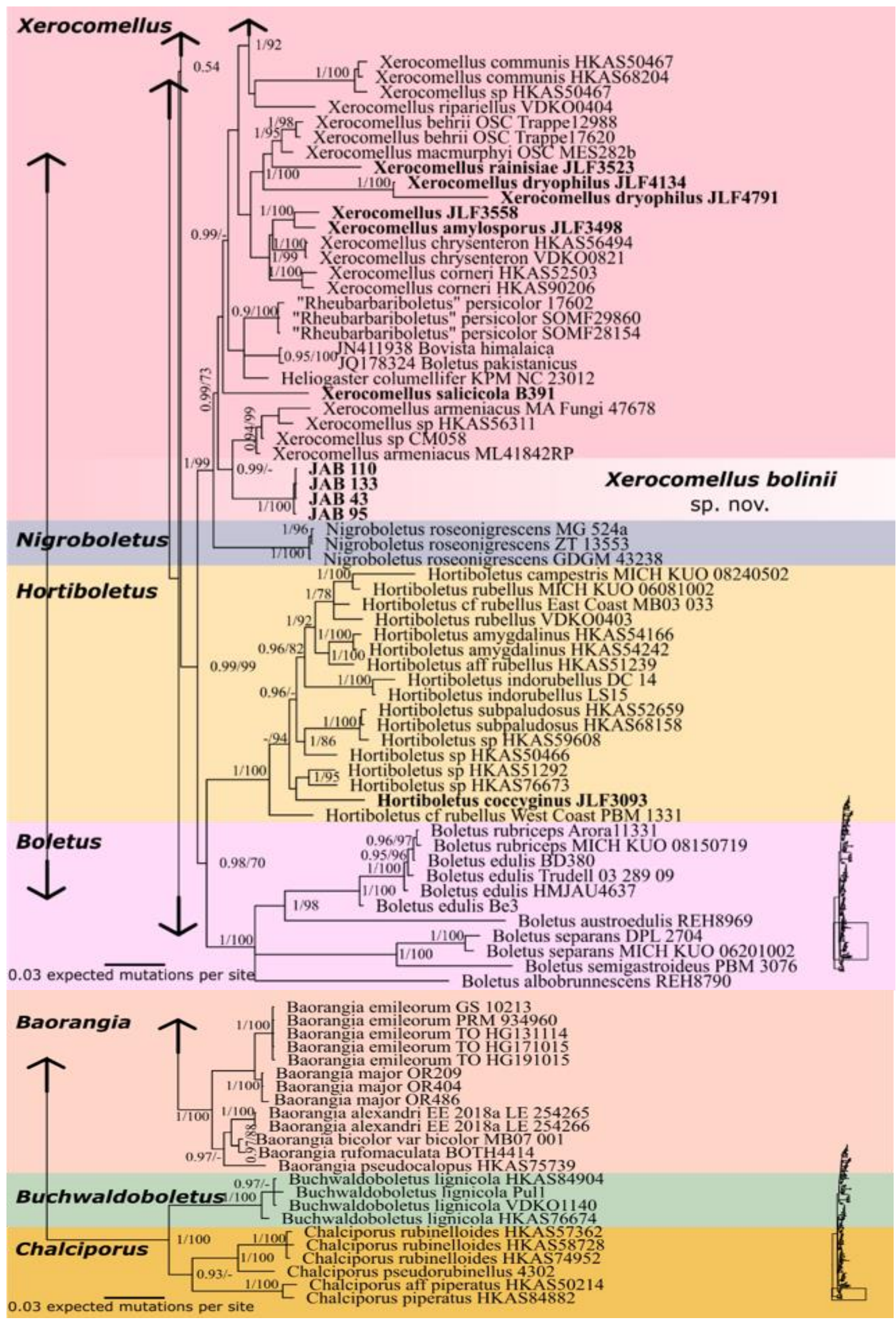

Figure 1 - Continued. 


\section{Results}

\section{Phylogenetic analyses}

The final dataset consisted of 305 specimens comprising 141 ITS, 234 28S, 140 RPB1, 165 $R P B 2,216$ TEF1 sequences (Supplementary Table 1). A total of 143 sequences were generated for this study. The six species from this study were distributed across five genera. One species of Aureoboletus forms a strongly supported clade (0.96 BPP, 96 bootstrap replicate support), with somewhat strong support (0.91 BPP, 94 bootstrap replicate support) as a sister clade with Aureoboletus auriporus (Peck) Pouzar. A strongly supported clade in Hemileccinum with somewhat strong support (0.96 BPP, but <70 bootstrap replicate support) was sister to a clade of Hemileccinum subglabripes (Peck) Halling. In Xerocomellus, a strongly supported clade was sister to an unnamed Xerocomellus sp. (HKAS 56311) from China. Three specimens of Nigroboletus roseonigrescens Gelardi, Vizzini, E. Horak, T.H. Li \& Ming were strongly supported as basal to all Xerocomellus sequences included in the analyses. Two species in Cyanoboletus were recovered in the analyses. This first Cyanoboletus species is in a strongly supported clade (1 BPP, 98 bootstrap replicate support) containing Cyanoboletus pulverulentus s.str., and Cyanoboletus sinopulverulentus (Gelardi \& Vizzini) Gelardi, Vizzini \& Simonini, although C. sinopulverulentus did not receive strong support as sister to either of these species. The second Cyanoboletus species formed a strongly supported sister clade to an unnamed Cyanoboletus sp. (HKAS 76850) from China, and a clade containing Cyanoboletus instabilis (W.F. Chiu) G. Wu \& Zhu L. Yang. A species of Lanmaoa formed a strongly supported sister clade to Lanmaoa roseocrispans A.E. Bessette, A.R. Bessette, Nuhn \& Halling. Pulchroboletus rubricitrinus (Murrill) Farid \& A.R. Franck, which was strongly supported as a sister clade to Pulchroboletus roseoalbidus (Alessio \& Littini) Gelardi, Vizzini \& Simonini, was consistent with the results from the nucDNA analysis in Farid et al. (2017). Our collection of Exsudoporus floridanus formed a strongly supported clade with Exsudoporus floridanus from Belize (1.0 BPP, 100 bootstrap replicate support), while the Exsudoporus clade was strongly supported as sister to Butyriboletus (1.0 BPP, 0.96 bootstrap replicate support).

Aureoboletus pseudoauriporus J.A. Bolin, A.R. Bessette, A.E. Bessette, L.V. Kudzma' A. Farid \& J.L. Frank sp. nov.

MycoBank number: MB840856; Facesoffungi number: FoF 10467

Figs 2, 10D-F

Etymology - The epithet pseudoauriporus is from the Latin "pseudo" = false in reference to this bolete so closely resembling, but differing from, Aureoboletus auriporus.

Typification - USA, Florida, Palm Beach County, Jupiter, Abacoa Natural Area, 1 Mar 2019, J.A. Bolin 320 (holotype USF 301510).

Diagnosis - Medium-sized basidiocarps with a glabrous, non-viscid pinkish tan unchanging pileus that becomes tan with age, or sometimes retains pinkish tones. The hymenophore is bright yellow when young, becomes darker yellow and then dingy yellow with age, and does not stain when bruised or cut. The stipe is typically longitudinally striate for one-third or more of its length. Basidiospores measure (14-)15-17(-18) $\times 5-6.5 \mu \mathrm{m}$.

Description - Pileus 5-8.5 cm broad, convex at first, remaining so well into maturity; surface glabrous, color variable, pinkish to pinkish red or pinkish tan, usually losing pinkish tones when mature, unchanging when bruised, tastes acidic; margin incurved, even or narrowly sterile; staining pale yellow-orange then fading to light brown with the application of $\mathrm{KOH}$, pale blue-green fading quickly or slowly with $\mathrm{NH}_{4} \mathrm{OH}$, slowly staining light greenish gray or negative with $\mathrm{FeSO}_{4}$. Context white, unchanging or faintly and slowly turning pink or light yellow near the hymenium; staining yellow-orange with $\mathrm{KOH}$, slowly light greenish gray or negative with $\mathrm{NH}_{4} \mathrm{OH}$, and light blue-green or negative with $\mathrm{FeSO}_{4}$; odor and taste not distinctive. Hymenophore tubulose, bright yellow when young, becoming darker yellow and then dingy yellow with age, not staining when bruised or cut; pores rounded, 1-2 per mm; tubes 4-12 mm deep. Stipe 4-6 cm long, 8-12 $\mathrm{mm}$ at the apex, 1-1.4 $\mathrm{cm}$ thick at the base, typically equal or slightly enlarged downward, sometimes with a pinched base; surface typically dry but viscid when wet, typically longitudinally striate for one-third or more of its 
length, whitish, sometimes with pale pink tones, not staining when bruised; context white, firm and woody toward the base, often staining faintly pinkish; with white basal mycelium.

Basidiospores light to medium brown in fresh deposit, $(14-) 15-17(-18) \times 5-6.5 \mu \mathrm{m}, \mathrm{n}=30$, $\mathrm{Q}=2.79$, elliptical in face view, inequilateral in profile, thick-walled, smooth, lacking an apical pore, yellow-brown in $\mathrm{KOH}$ or Melzer's. Basidia 25-38 $\times 8-13 \mu \mathrm{m}$, clavate, 2-sterigmate, hyaline in $\mathrm{KOH}$ or Melzer's. Basidioles 12-23 × 6.5-8 $\mu \mathrm{m}$, clavate, thin-walled, hyaline in $\mathrm{KOH}$ or Melzer's. Hymenial cystidia 30-50 $\times 10-15 \mu \mathrm{m}$, cylindrical, sometimes with a capitate to capitulate apex. Hymenophoral trama boletoid, with lateral elements, 4-12 $\mu \mathrm{m}$ wide, moderately divergent, hyaline in KOH or Melzer's. Pileipellis an ixotrichoderm, terminal elements 7-22 $\mu \mathrm{m}$ wide, highly variable, thin-walled, smooth, hyaline in $\mathrm{KOH}$, with golden yellow contents in Melzer's. Pileus trama hyphae loosely interwoven, highly variable, 6-32 $\mu \mathrm{m}$ wide, smooth, thin-walled, hyaline in $\mathrm{KOH}$ or Melzer's. Stipitipellis mostly parallel, slightly interwoven, 4-12 $\mu \mathrm{m}$ wide, hyaline in $\mathrm{KOH}$ or Melzer's, with fascicles of clavate or fusiform caulocystidia. Caulocystidia of two types; clavate, 24$42 \times 12-22 \mu \mathrm{m}$, with yellowish contents in $\mathrm{KOH}$, thin-walled, smooth; fusiform 32-39 $\times 8-12 \mu \mathrm{m}$, hyaline in $\mathrm{KOH}$, thin-walled, smooth. Stipe trama interwoven, 6-13 $\mu \mathrm{m}$ wide, hyaline in $\mathrm{KOH}$ or Melzer's, thin-walled, smooth. Clamp connections absent.
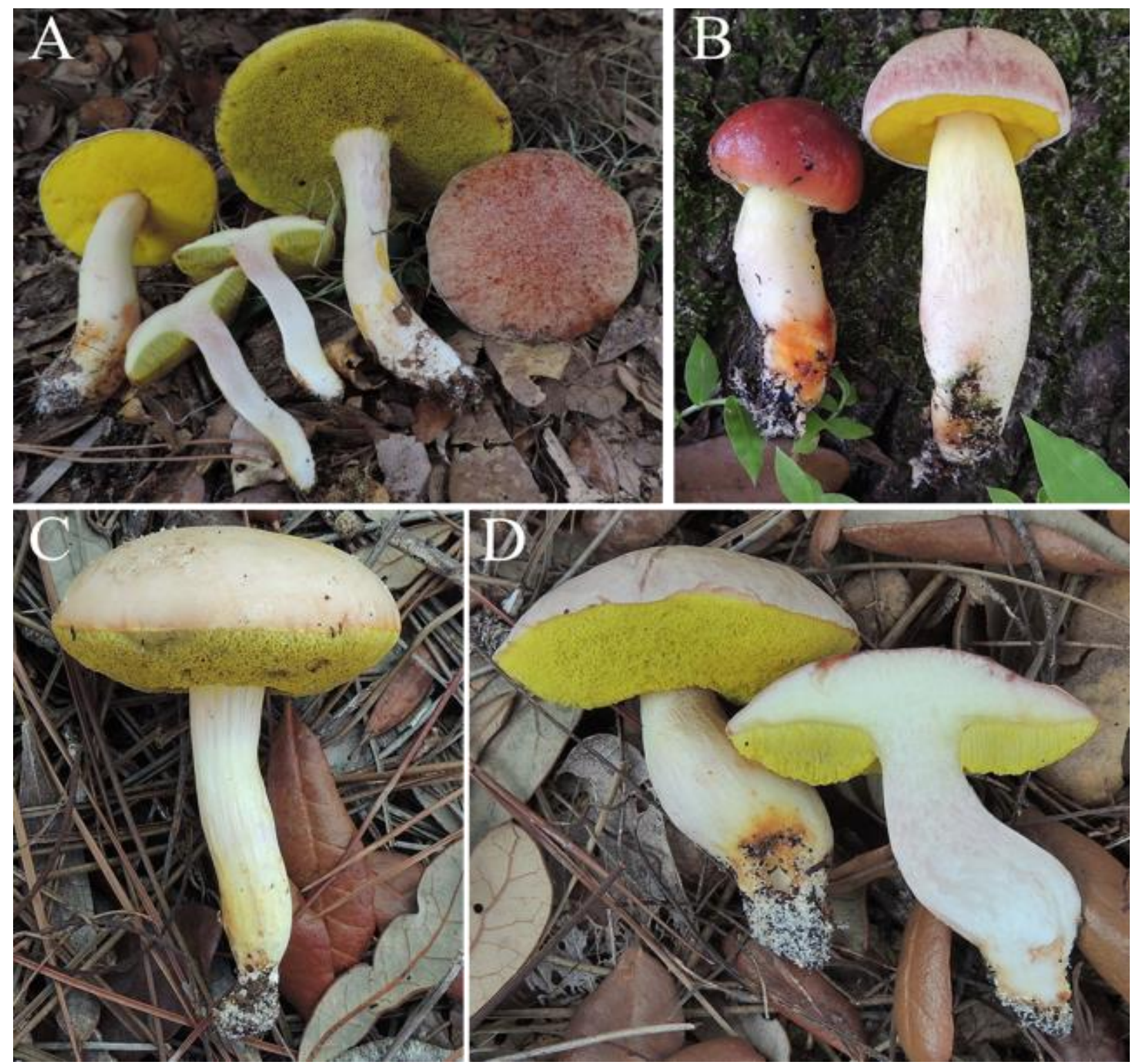

Figure 2 - Field photograph of Aureoboletus pseudoauriporus. A J.A. Bolin 488. B J.A. Bolin 157. C J.A. Bolin 124. D J.A. Bolin 130. Photo credit: J.A. Bolin. 
Habit, Habitat \& Distribution - solitary or scattered in sandy soil with oak in a scrubby flatwood community; known from central Florida, distribution limits yet to be determined.

Material examined - USA, Florida, Hillsborough County, Brandon, S of Camden Visconti entrance pond, adjacent to canal, $27^{\circ} 55^{\prime} 27.9^{\prime \prime} \mathrm{N} 82^{\circ} 20^{\prime} 22.9^{\prime \prime} \mathrm{W}, 5$ Oct 2016, A. Farid 501 (USF 288287); Tampa, Violet Cury Nature Preserve, 4 Jun 2017, A. Farid 592 (USF 301502); Tampa, Trout Creek Nature Preserve, Xeric hammock beneath Quercus geminata, 3 May 2019, A. Farid 919 (USF 301507); Lake County, Lake Louisa State Park, Clermont, 24 Oct 2019, J.A. Bolin 448 (USF 301492); Miami-Dade County, Everglades National Park, 5 Jul 2019, A. Farid 959 with A.R. Franck and R.E. O'Donovan (EVER 144770); Palm Beach County, Frenchman's Forest natural Area, 28 May 2018, J.A. Bolin 167 (USF 301497); Hypoluxo Scrub Natural Area, Lantana, 21 Nov 2017, J.A. Bolin 80 (USF 301487); ibid., 70 Sep 2019, 7 Sep 2019, J.A. Bolin 106 (USF 301489); ibid., 6 Nov 2017, J.A. Bolin 130, (USF 301493); Jupiter, Abacoa Natural Area, 1 Mar 2019, J.A. Bolin 320 (holotype USF 301510); ibid., 13 Aug 2019, J.A. Bolin 418 (USF 301483).

Notes - This species is a part of a cryptic species complex. It greatly resembles Aureoboletus auriporus (Peck) Pouzar, and its distribution limits are yet to be established. Aureoboletus auriporus differs from A. pseudoauriporus by the lack of longitudinal striations on the stipe. The pileus of $A$. auriporus is reported to turn red with the application of $\mathrm{NH}_{4} \mathrm{OH}$ (Baroni 2017). The spore size of $A$. auriporus was not originally reported in the protologue, though Peck (1889) later provided an expanded description and reported the spores as 7.5-10 $\times 4-5 \mu \mathrm{m}$. Both (1998) studied the type specimen, obtaining a spore size of $9.8-15.5 \times 3.96-5.75 \mu \mathrm{m}$, with a mean dimension of $13.15 \times 4.73$ $\mu \mathrm{m}, \mathrm{Q}=2.12-3.39, \mathrm{Qm}=2.75$. Both (1998) also provided a description based on collections primarily from New York and Rhode Island, but also included a specimen from Tennessee, and did not include the type specimen. The spores reported were slightly larger than the type, at 11.0-16.05 $\times 4.4-6.38 \mu \mathrm{m}$, mean dimension $14.36 \times 5.19 \mu \mathrm{m}$, and the spore quotient was similar, at $\mathrm{Q}=2.2-$ $3.19, \mathrm{Qm}=2.78$. The spores of A. pseudoauriporus are somewhat larger, at $(14-) 15-17(-18) \times 5-$ $6.5 \mu \mathrm{m}, \times=16.45 \times 5.92 \mu \mathrm{m}$, and the spore quotient is nearly identical, at $\mathrm{Q}=2.79$.

Aureoboletus viridiflavus Coker \& Beers ex Klofac is a similar species, and has been treated as a synonym of A. auriporus in the past (Singer 1947, Both 1998), which differs primarily by the pileus colors, which was described as "olivaceous gold with reddish areas", the pileus when young tomentose-felted, less viscid, a lack of distinctly projecting margin, the hymenophore longer, to 17.5 $\mathrm{mm}$ (4-12 $\mathrm{mm}$ in A. pseudoauriporus), and the stipe, which bruises "brick red" and is not viscid (white, sometimes with pale pink tones, and not bruising in A. pseudoauriporus). The spore size is similar to A. auriporus, reported as $11.5-15(-16.6) \times 4-5 \mu \mathrm{m}$ in the protologue. Aureoboletus pseudoauriporus has somewhat longer and wider spores, measuring (14-)15-17(-18) $\times 5-6.5 \mu \mathrm{m}$. Aureoboletus subacidus (Murrill ex Singer) Pouzar is a somewhat similar species that shares reddish tones in the pileus, citrine yellow tubes, a whitish stipe, occurs in Florida, and is associated with Quercus spp. It can readily be distinguished from A. pseudoauriporus by the presence of the floccose yellow velar remnants left on the upper portion of the stipe, the scrobiculate pileus, and the yellow pileal context (Singer 1947).

So far, A. pseudoauriporus is the only species in the complex known from Florida. Although A. pseudoauriporus has been observed in southeastern Georgia (USA) by the authors, no collections were made. Aureoboletus innixus (Frost) Halling, A. R. Bessette \& A. E. Bessette is similar but it has a dry, somewhat velutinous, dull reddish-brown pileus, and lacks longitudinal striations on its stipe. Aureoboletus roxanae (Frost) Klofac has whitish pores when young which eventually become pale yellow, and a yellow to pale orange-yellow stipe with a distinct dull orange zone at the apex.

Cyanoboletus bessettei A.R. Bessette, L.V. Kudzma, \& A. Farid sp. nov.

MycoBank number: MB 840857; Facesoffungi number: FoF 10466

Figs 3, 10G-I

Etymology - The epithet bessettei honors American mycologist, Alan E. Bessette.

Typification - USA, South Carolina, Berkeley County, Francis Marion National Forest, State Route 402, approximately 1.25 mi. north of Huger, under oak and pine, 17 Sep 2016, A.R. Bessette ARB1393 (Holotype USF 301500). 
Diagnosis - Medium-sized basidiocarps with a dry, reddish brown to buffy brown pileus and a reddish-brown stipe with a pale-yellow apex and white basal mycelium. The hymenophore surface is pale yellow and stains blue-green then olive when bruised. It has pale yellow context that stains blue-green then slowly turns peach to dull pinkish orange when exposed. The basidiospores measure $(8-) 9-11(-12) \times 3.5-5 \mu \mathrm{m}$ and are narrowly ovate to subelliptic. It fruits on the ground with oak and pine during fall.

Description - Pileus 2.7-8 cm broad, convex with an incurved margin that remains into maturity; surface subtomentose to nearly glabrous, dry, buffy brown overall when very young, becoming paler toward the margin and retaining darker brownish coloration on the disc at maturity, staining blue-green then dark olive-green and finally brown when bruised; margin with a narrow band of sterile tissue, sometimes undulating or lobed in age; context pale yellow, staining blue-green then slowly turning peach to dull pinkish orange when exposed; odor unpleasant, odd, chemical-like; taste slightly acidic or not distinctive. Cuticle stains dark amber with the application of $\mathrm{KOH}$, pale olive with $\mathrm{FeSO}_{4}$, and amber with an expanding blue-green outer ring with $\mathrm{NH}_{4} \mathrm{OH}$. Context stains yellow, then pale orange with the application of $\mathrm{KOH}$ or $\mathrm{NH}_{4} \mathrm{OH}$ and is negative with $\mathrm{FeSO}_{4}$. Hymenophore tubulose, pale yellow, staining blue-green, then olive when bruised; pores angular to irregular, 2-3 per $\mathrm{mm}$; tubes $4-8 \mathrm{~mm}$ deep. Stipe $2.5-4 \mathrm{~cm}$ long, 1-2 $\mathrm{cm}$ thick, nearly equal or flaring at the apex, pinched at the base; surface longitudinally striate, dry, distinctly pale yellow at the apex, reddish brown below, with white basal mycelium, staining blue-green then reddish-brown; context pale yellow, slowly staining blue-green at the apex, then becoming bright chrome yellow.

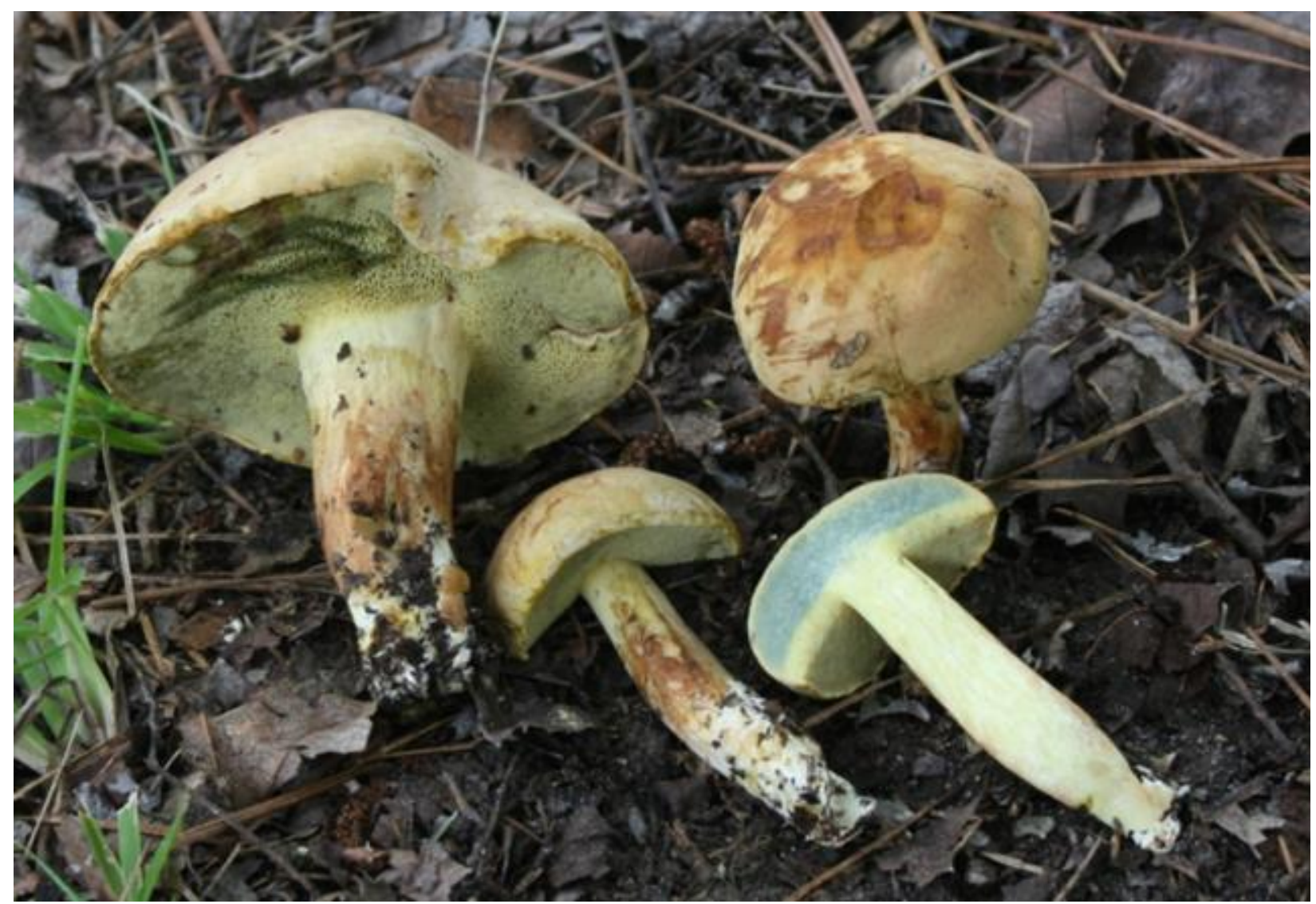

Figure 3 - Field photograph of Cyanoboletus bessettei (ARB 1393). Photo credit: A.R. Bessette.

Basidiospores olive-brown in fresh deposit, (8-)9-11(-12) $\times 3.5-5 \mu \mathrm{m}, \mathrm{n}=30, \mathrm{Q}=2.30$, narrowly ovate to subelliptic in face view, obscurely inequilateral in profile, thin-walled, smooth, lacking an apical pore, yellowish in $\mathrm{KOH}$ or Melzer's, inamyloid; spores sometimes collapsing when mounted in Melzer's. Basidia 23-36 × 5.5-9 $\mu \mathrm{m}$, mostly clavate, few cylindro-clavate, (2)4sterigmate, hyaline in KOH, grayish yellow in Melzer's. Basidioles 19-31 × 5-8.5 $\mu \mathrm{m}$, clavate. 
Hymenial cystidia abundant, sometimes in fascicles, 36-51 $\times 8-11 \mu \mathrm{m}$, ventricose-rostrate, some with an elongated neck, thin-walled, smooth, yellowish in $\mathrm{KOH}$, non-reactive in Melzer's. Hymenophoral trama boletoid, with lateral elements, 3.5-7 $\mu \mathrm{m}$, wide, moderately divergent, hyaline to grayish yellow in $\mathrm{KOH}$ or Melzer's. Pileipellis a tangled layer of repent tubular hyphae, 3.5-5.8 $\mu \mathrm{m}$ wide, with cylindrical, rounded end cells, thin-walled, smooth, hyaline to grayish yellow in $\mathrm{KOH}$, yellowish in Melzer's. Pileus trama hyphae loosely interwoven, 4.5-13 $\mu \mathrm{m}$, smooth, thin-walled, hyaline in KOH, yellowish in Melzer's. Stipitipellis hyphae mostly parallel, slightly interwoven, 3$6.5 \mu \mathrm{m}$, hyaline in $\mathrm{KOH}$, yellowish in Melzer's. Stipe trama subparallel, interwoven, 5.2-14 $\mu \mathrm{m}$, hyaline in $\mathrm{KOH}$, yellowish in Melzer's. Caulocystidia none observed. Clamp connections absent.

Habitat and Distribution - Scattered or in groups in sparsely grassy areas and sandy soil in association with Quercus and Pinus in fall (September), in southeastern United States, known only from South Carolina.

Notes - The combination of distinctive staining reactions and very small spore size is distinct. To date, it is known only from the type location in southeastern South Carolina, United States. Caloboletus inedulis (Murrill) Vizzini is superficially similar with a pale yellow hymenophore that becomes olive yellow at maturity and stains dark blue then brownish when bruised. It has a reticulated pale-yellow stipe that may have pinkish tones at the apex and/or pinkish tints below, and bitter tasting context.

Cyanoboletus cyaneitinctus (Murrill) A. Farid, A.R. Franck \& J.A. Bolin comb. nov.

MycoBank number: MB 840858; Facesoffungi number: FoF 10465

Figs 4, 5A-G, 10A-C

Basionym - Ceriomyces cyaneitinctus Murrill, Lloydia 6: 225 (1943).

Synonyms - Boletus cyaneitinctus (Murrill) Murrill, Lloydia 6: 228 (1943).

Typification - USA, Florida, Alachua County, Gainesville, Kelley’s Hammock, 3 Aug 1938, West and Murrill s.n. (holotype FLAS-F-17986); Hillsborough County, Tampa, Learning Gate Community grounds, 4 May 2019, A. Farid 920 (epitype here designated USF 301499).

= Boletus mutabilis Morgan, J. Cincinnati Soc. Nat. Hist. 7: 6 (1884), nom. illegit., Art. 53.1.

Diagnosis - Brownish or rarely reddish pulvinate pileus, bright yellow hymenophore, stipe, and context, all surfaces rapidly and brilliantly cyanescent.

Description - Pileus 3-8 cm wide, pulvinate or convex when young becoming broadly convex at maturity, bister, umber, mahogany, and dark brown overall, rarely entirely red in the pileus, glabrous to tomentose, tacky when wet, sometimes rimulose at maturity, blackening instantly where handled. Hymenophore tubulose, yellow, darkening to a gold color when mature, tubes 5-20 mm long, bluing instantly and strongly when handled; pore mouths subangular when mature, $0.5-1 \mathrm{~mm}$ in diameter. Stipe 3-6 $\times 0.5-2 \mathrm{~cm}$, equal to ventricose, bright yellow, smooth or sometimes reticulate on the upper third, sometimes with flushes of reddish to brownish-red floccons, particularly towards the base of the stipe, bluing instantly and strongly when handled, basal mycelium white to yellowish white. Context concolorous with stipe surface, often with red pigments at the very base of the stipital context, blueing instantly and strongly, fading to pale yellow. $\mathrm{KOH}$ on pileus dark maroon to black, red elsewhere; $\mathrm{FeSO}_{4}$ negative, erasing blue stains from flesh.

Basidiospores (11)11.5-15(16) $\times 4-6 \mu \mathrm{m}, \mathrm{n}=30, \mathrm{Q}=2.4$, fusiform, sometimes with a suprahilar depression present. Basidia 25-50 × 8-10 $\mu \mathrm{m}$, 4-spored, thin-walled, hyaline, clavate to pyriform; sterigmata 1-2 $\mu \mathrm{m}$, occasionally pigmented like pleruocystidia. Basidioles similarly sized and shaped. Pleurocystidia 30-60 × 7-10 $\mu \mathrm{m}$, fusoid to ampullaceous, hyaline or sometimes encrusted. Cheilocystidia similar to pleurocystidia. Pilepellis a trichodermium of strongly interwoven, filamentous, sinuous, rarely branched hyphae, erect or repent in most of the terminal elements, collapsing into a cutis, terminal elements cylindrical, apices rounded or somewhat pointed, 20-70 $\times 5-10 \mu \mathrm{m}$, smooth-walled, inamyloid, hyaline to golden-yellow or somewhat brownish in water and $5 \% \mathrm{KOH}$. Clamp connections absent.

Habitat and Distribution - Basidiomes typically occurring singly or more rarely gregariously, widely distributed in eastern North America. 
Material examined - USA, Florida, Alachua Co., Gainesville, 2 Oct 1949, W.A. Murrill s.n. (FLAS F16163); ibid., lawn under pecan [Carya illinoinensis], 7 Nov 1947, W.A. Murrill s.n. (FLAS F40835); ibid., Kelley's Hammock, 3 Aug 1938, West and W.A. Murrill s.n. (holotype FLAS F17986); ibid., yard at 936 NW 30 ${ }^{\text {th }}$ Ave., 9 Aug 1980, G.L. Benny s.n. (FLAS F52704); ibid., lawn under laurel oak [Quercus laurifolia], 1 Aug 1947, Murrill s.n. (FLAS F19093); ibid., shaded yard, 6 Nov. 1950, R. Bennett s.n. (FLAS F59706); ibid., lawn der hardwoods, 13 Oct 1950, R. Bennett s.n. (FLAS F19647); ibid., $19 \times 1950$, R. Bennett s.n. (FLAS F 40863); ibid., lawn on $18^{\text {th }}$ block of NW 11 place, Sept 12 1968, J. Kimbrough s.n. (FLAS F48020); ibid., under large live oak [Quercus virginiana] 10 mi. SE of Gainesville, on Palatka Rd., 2 Nov 1947, G.F. Weber s.n. (FLAS F40837); Hillsborough Co., Alafia River State Park, 17 Jul 2018, J. Bolin 177 (USF 300090); Hillsborough County, Tampa, University of South Florida Tampa Campus, entrance area off of Leroy Collins Boulevard, 11 Jun 2016, A. Farid 340 (USF 288424); USF campus, 22 May 2018, Franck 4352 (USF 297911); Tampa, Learning Gate Community grounds, 4 May 2019, A. Farid 920 (epitype here designated USF 301499); Palm Beach Co., Frenchman's Reserve, 1 III 2019, J. Bolin 324 (USF 300081); Prosperity Oaks, 2 Mar 2019, J. Bolin 325 (USF 300080). OHIO: Hocking Co., 4 Aug 2018, J. Bolin 185 (USF 300091); Vinton Co. 5 Aug 2018, J. Bolin 184 (USF 300085). TENNESSEE: Knox Co., Knoxville, Tobler Rd., 4 Sept 1949, A.J. Sharps s.n. with L.R. Hesler (FLAS-F-53755).

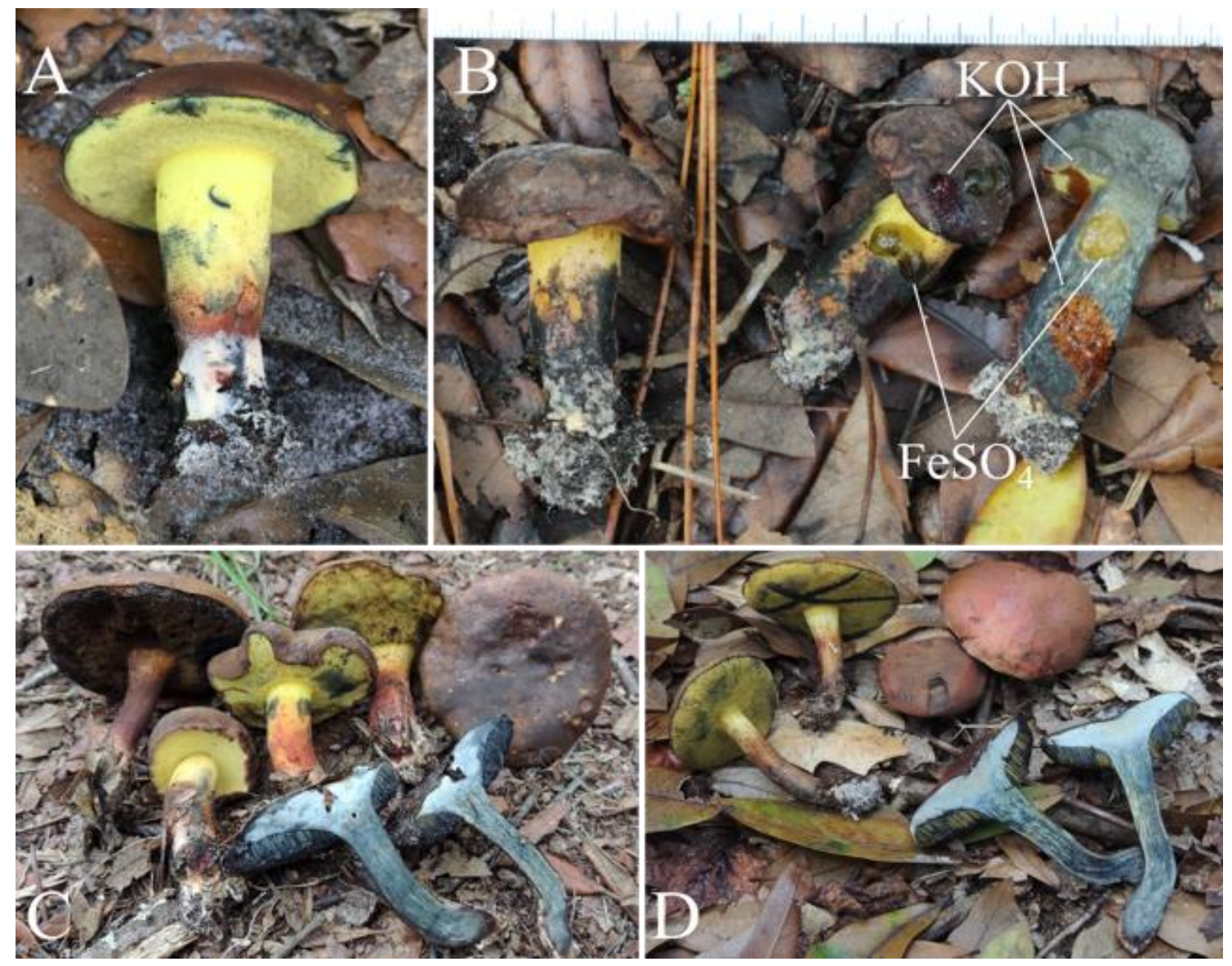

Figure 4 - Field photographs of Cyanoboletus cyaneitinctus. A A. Farid 920. B A. Farid 340. Macrochemical tests of basidiomes are labelled. The scale in the top is in centimeters. C JAB 324. D JAB 389. Photo credits: J.A. Bolin.

Notes - Cyanoboletus Gelardi, Vizzini, \& Simonini is in the Pulveroboletus clade, and is comprised of eight species. Cyanoboletus was described in 2014 (Vizzini 2014) with Boletus pulverulentus Opat. as the type species for the genus. Although no molecular analysis was provided in the protologue, previous molecular analyses demonstrated several species (now in Cyanoboletus) 
were not related to Boletus L. s. str. (Gelardi et al. 2013, Wu et al. 2014). Cyanoboletus is distinguished from other boletoid genera by its yellowish brown to dark brown pileus, rapidly blueing context and hymenophore, and smooth basidiospores.

Cyanoboletus cyaneitinctus is very similar to the closely related C. pulverulentus (Opat.) Gelardi, Vizzini \& Simonini. Both are boletes with a dark brown pileus, small pores (1-2 per mm), and yellow stipes with brown punctae; all surfaces instantly bruise blue. The European name has historically been applied to this species in North America (Singer 1947, Smith \& Thiers 1971, Bessette et al. 2000, 2017), but we are here treating them as separate species based on our molecular analyses (Fig. 1) and morphological studies. The spore quotient $\mathrm{Q}$ is lower in C. cyaneitinctus at $\mathrm{Q}$ $=2.4$ (with the Q usually between 2.3-2.5) compared to 2.6-2.9 in C. pulverulentus (Gelardi et al. 2013). These two species are geographically separated, with $C$. cyaneitinctus occurring in eastern North America and the latter found in Europe. Cyanoboletus sinopulverulentus, which is sister to C. cyaneitinctus (Fig. 1) is distinguished from C. cyaneitinctus and C. pulverulentus by its evenly dark brown stipe (lacking the reddish and yellow tones often present in the other two species), which is more heavily pruinose to scissurate. Cyanoboletus sinopulverulentus has predominately 2 -spored basidia (4-spored in the other two taxa), and can also be distinguished on the basis of its $\mathrm{Q}$ value, which is reported as 2.17-2.45 (Gelardi et al. 2013), smaller than either of the other two Cyanoboletus species mentioned here.

Boletus mutabilis Morgan is an earlier but illegitimate name for this American species (see Art. 53.1). Thus, the oldest name we have to apply to the North American species is $C$. cyaneitinctus. Singer (1947) treated $C$. cyaneitinctus as a synonym of $C$. pulverulentus. The type of $C$. cyaneitinctus was examined, and matched the other North American collections examined. This type material is quite old and not in good condition; thus, we have designated an epitype, and have included images (Figs 4, 5A-G) as well as published molecular data. Cyanoboletus cyaneitinctus and C. pulverulentus are difficult to distinguish morphologically.

Cyanoboletus cyaneitinctus forma reticulatus (Snell, E.A. Dick \& Hesler) A. Farid comb. nov.

MycoBank number: MB 840859; Facesoffungi number: FoF 10465

Fig. $5 \mathrm{H}$

Basionym - Boletus pulverulentus f. reticulatus Snell, E.A. Dick \& Hesler, Mycologia 43(3): 362. 1951.

Typification - USA, Tennesse, Knox County, Knoxville, on an old sod yard near Robinia and Ligustrum and not far from Ulmus but with no accurate indication of mycorrhizal associate, 4 Sept 1949, L.R. Hesler 19314 (holotype TENN-F-019314, isotype SFSU -F-000439).

Material examined - USA, Florida, Hillsborough Co., Brandon, under Quercus laurifolia, 5 Jun 2020, Farid 1035 (USF 301501).

Notes - Cyanoboletus cyaneitinctus f. reticulatus differs from the type form by the reticulation present over the upper stipe. The protologue states all other macro- and micromorphological characters are consistent, and this is consistent with our observations.

Hemileccinum floridanum J.A. Bolin, A.E. Bessette, A.R. Bessette, L.V. Kudzma, A. Farid \& J.L. Frank sp. nov.

MycoBank number: MB 840861; Facesoffungi number: FoF 10464

Figs 6, 10J-L

Etymology - A reference to Florida where this species was first collected and described.

Typification - USA, Florida, Lake County, Lake Louisa State Park, 4 Sep 2016, J. A. Bolin 142 (holotype USF 301495).

Diagnosis - Medium-sized to large basidiocarps with a dry to slightly tacky, reddish brown to chestnut brown pileus and a whitish stipe that becomes pale yellow at the apex and has a white basal mycelium. The hymenophore is bright yellow when young, becomes darker brownish yellow as it matures, and does not stain when bruised. It has white context that slowly stains yellow often from the margin toward the center. The basidiospores measure (10-)13-16(-17) $\times 4.5-6 \mu \mathrm{m}$ and are elliptical. It fruits on the ground with oak from late spring through fall. 

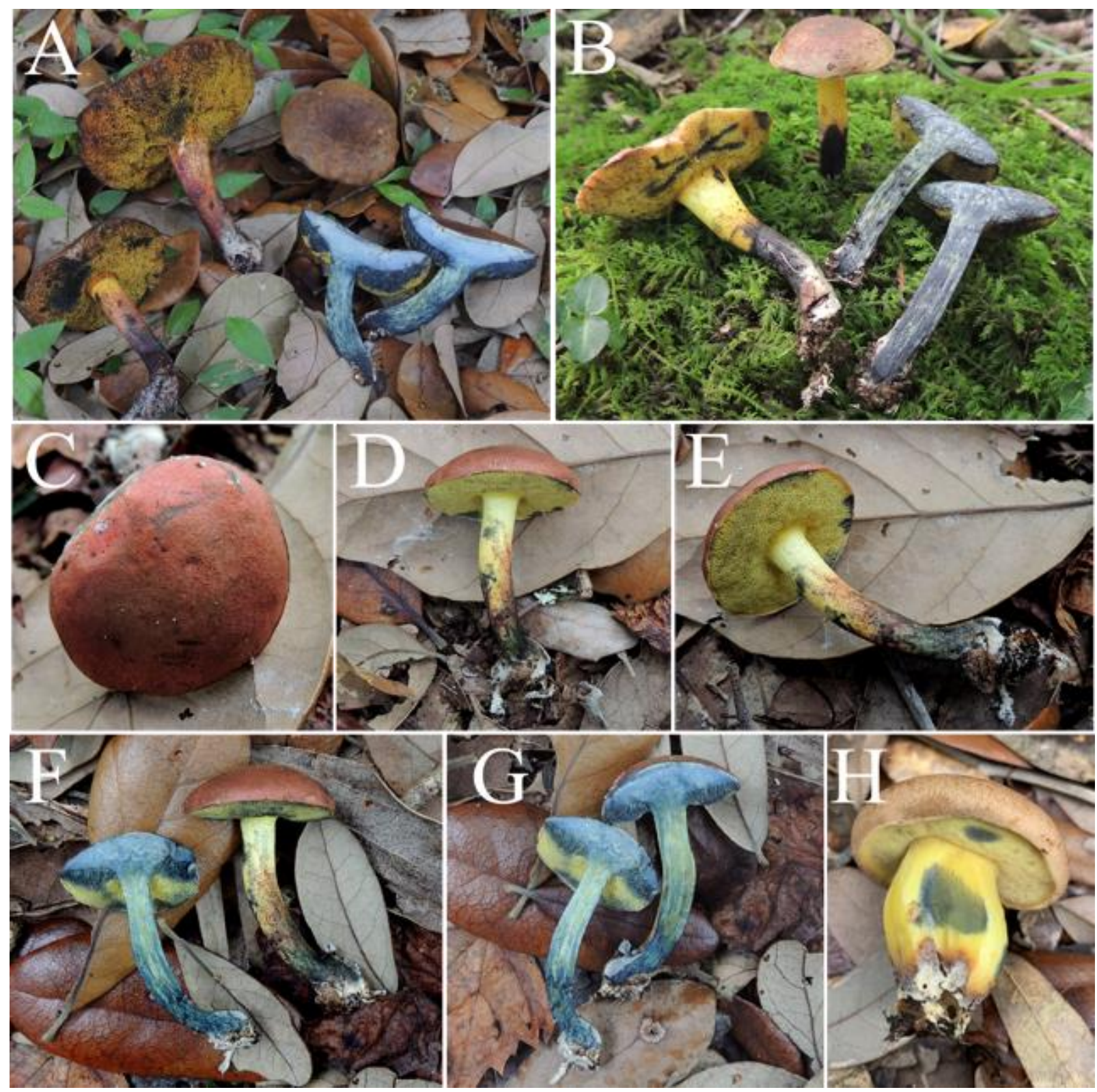

Figure 5 - Field photographs of Cyanoboletus cyaneitinctus. A JAB 325. B JAB 185. C-G JAB 324. H Cyanoboletus cyaneitinctus f. reticulatus Farid 1035. Photo credits: A-G J.A. Bolin, H A Farid.

Description - Pileus $2.8-12.5 \mathrm{~cm}$ wide, convex becoming broadly convex to nearly plane in age; surface dry to slightly tacky, smooth to somewhat wrinkled and uneven, glabrous to finely velvety, sometimes with a whitish bloom when young, reddish brown to chestnut brown, cuticle acidic tasting or not distinctive; margin even or nearly so. Hymenophore tubulose 3-12 mm deep, pore surface bright yellow when young, maturing to darker brownish-yellow, not staining when bruised, depressed near the stipe in age, easily detached from the pileus context; pores angular to irregular, 2-3 per $\mathrm{mm}$. Stipe $4-9.5 \mathrm{~cm}$ long $\times 1-3 \mathrm{~cm}$ thick, nearly equal or enlarged in either direction, with a pinched base; surface dry, longitudinally striate, nearly glabrous to very weakly scurfypunctate, not reticulate; whitish overall on young specimens, becoming pale yellow at the apex with variable reddish tints and streaks over a whitish to pale yellow ground color below, with white basal mycelium. Context in the pileus white, slowly staining yellow often from the margin toward the center, with a slight pinkish-red coloration beneath the cuticle; in the stipe, white, slowly staining yellowish from the pileus trama just above the hymenophore partly downward along the exterior stipe trama when exposed. Cuticle stains brownish red or light orange sometimes fading to light green with the application of $\mathrm{KOH}$, olive and then orange or amber with a green ring with $\mathrm{NH}_{4} \mathrm{OH}$, and 
dark orange-amber to orange with $\mathrm{FeSO}_{4}$. The context stains pale orange to yellow then fades with $\mathrm{KOH}$, is negative with $\mathrm{NH}_{4} \mathrm{OH}$, and negative or light greyish olive green with $\mathrm{FeSO}_{4}$. Odor slightly sour to not distinctive; taste not distinctive.

Basidiospores olive-brown in fresh deposit, (10-)13-16(-17) $\times 4.5-6 \mu \mathrm{m}, \mathrm{n}=30, \mathrm{Q}=2.86$, elliptical in face view, inequilateral in profile, thin-walled, smooth, lacking an apical pore, grayish yellow in KOH, brownish yellow in Melzer's. Basidia 32-38 $\times 8.5-10.5 \mu \mathrm{m}$, clavate, 4-sterigmate, sometimes 3- or 2-sterigmate, hyaline in $\mathrm{KOH}$, yellow in Melzer's, with granular, inamyloid contents. Basidioles 22-29 $\times 7.5-8.5 \mu \mathrm{m}$, clavate, hyaline in $\mathrm{KOH}$, yellow in Melzer's. Pleurocystidia 25-50 × 6-10 $\mathrm{m}$, hyaline, ventricose in the middle, ampullaceous at the apex, frequent near the pores. Pileipellis a cutis of loosely interwoven cylindric hyphae with markedly inflated, sphaerocyst-like oval to subglobose terminal cells, 11-33 $\times 15-22 \mu \mathrm{m}$, grayish yellow in $\mathrm{KOH}$, yellow to orange-yellow with granular contents in Melzer's; hyphae of the pileipellis 4-8.5 $\mu \mathrm{m}$ wide, thin-walled, smooth, grayish yellow in $\mathrm{KOH}$, yellow in Melzer's. Pileus trama hyphae loosely interwoven, highly variable, 4-16 $\mu \mathrm{m}$, with rounded terminal ends, thin-walled, smooth, hyaline in $\mathrm{KOH}$, yellow in Melzer's, inamyloid. Hymenophoral trama boletoid, with lateral elements 5-9 $\mu \mathrm{m}$, moderately divergent, thin-walled, smooth, hyaline to pale grayish yellow in $\mathrm{KOH}$, pale grayish yellow in Melzer's. Stipitipellis 4-17 $\mu \mathrm{m}$ wide, hyphae subparallel, highly variable, tubular with rounded ends and granular contents, thin-walled, smooth, hyaline in $\mathrm{KOH}$, yellow-brown in Melzer's, caulocystidia not observed. Stipe trama interwoven, 9-27 $\mu \mathrm{m}$, highly variable, tubular with rounded ends, thin-walled, smooth, hyaline in $\mathrm{KOH}$, hyaline to pale yellow in Melzer's. Clamp connections absent.
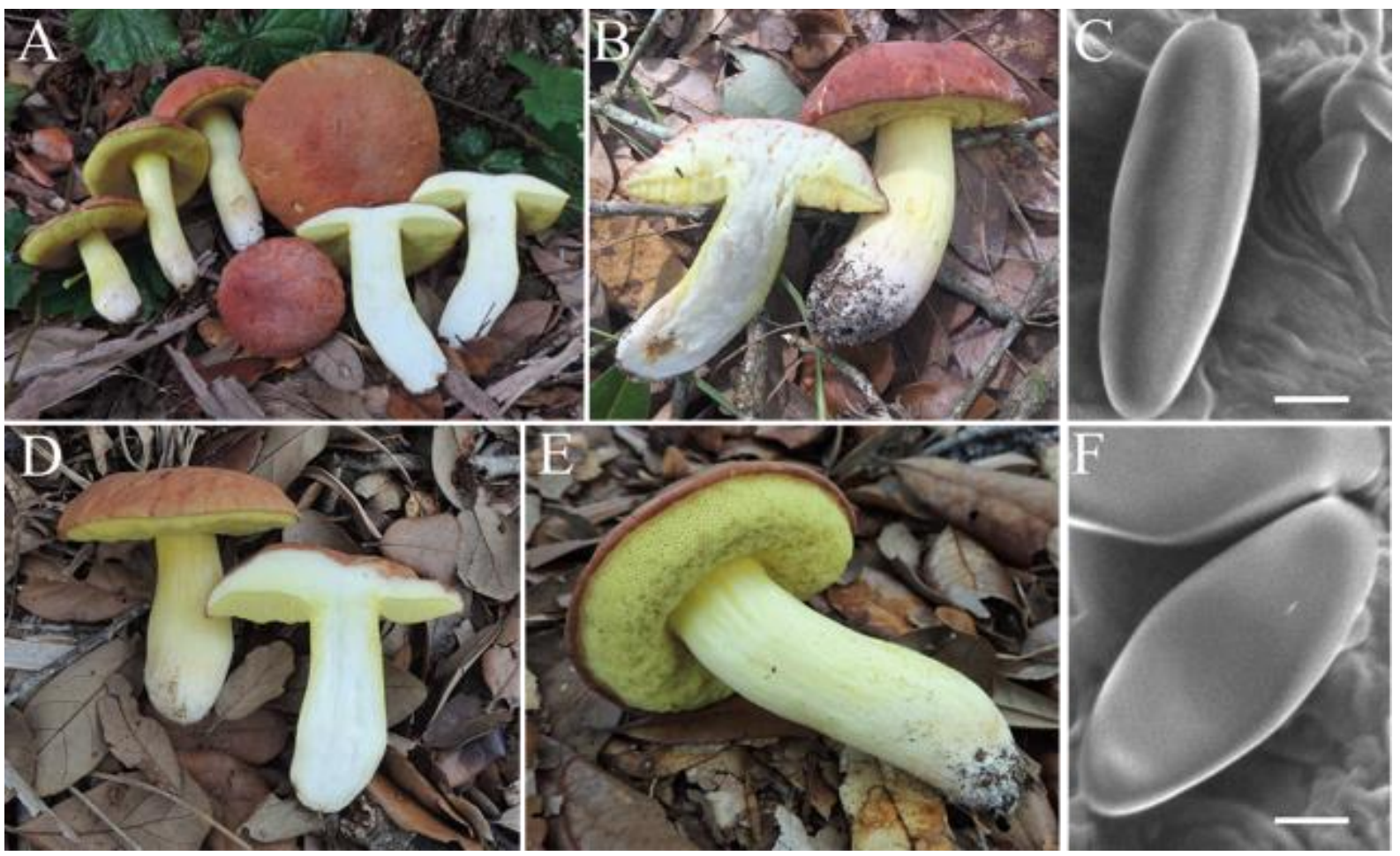

Figure 6 - Field photographs of Hemileccinum floridanum. A J.A. Bolin 142. B. J.A. Bolin 454. D J.A. Bolin 157. E J.A. Bolin 201. Photo credits: J.A. Bolin. C, F are SEM images of basidiospores from J.A. Bolin 454 (white bar $=4 \mu \mathrm{m}$ ).

Habit, Habitat and Distribution - Solitary, scattered or in groups on the ground with oak; known from Florida, potentially to North Carolina (Singer 1947).

Material examined - USA, Florida, Hillsborough County, Violet Cury Nature Preserve, 14 June 2017, A. Farid 625 (USF 301503); University of South Florida Tampa campus, trails near tennis courts in NE corner of campus, 4 Jun 2018, A. Farid 790 (USF 297572), ibid., 30 Oct 2019, A. Farid 
1032 (USF 301509). Lake County, Lake Louisa State Park, 4 Sept 2017, J.A. Bolin 142; Palm Beach County, Frenchman's Forest Natural Area, Jupiter 7 Nov 20 May 2018, J.A. Bolin 157 (USF 301488), ibid., 7 Nov 2019, J.A. Bolin 142 (USF 301495); ibid., 7 Nov 2019, J.A. Bolin 454 (USF 301491).

Notes - Hemileccinum subglabripes (Peck) R. Halling is very similar, but its stipe is furfuraceous to scabrous or fibrillose and pale to bright yellow. It has smaller narrower spores and smaller sphaerocyst-like elements that measure 10-24 $\mu \mathrm{m}$. Hemileccinum hortonii (A.H. Sm. \& Thiers) M. Kuo \& B. Ortiz is also similar, but it has a conspicuously pitted pileus, a smooth to lightly pruinose stipe that sometimes has delicate reticulation on the upper half, and pores that sometimes bruise blue. Hemileccinum rubropunctum (Peck) R. Halling \& B. Ortiz has a conspicuously punctate stipe, yellowish context, sometimes with an unpleasant odor reminiscent of stale cigarette butts in an ashtray and larger spores that measure (10) 16-22 $\times 5.5-7.5 \mu \mathrm{m}$. The basidiospores under SEM were smooth, lacking the very minute warts present in some species of Hemileccinum (Šutara 2008, Wu et al. 2014).

Lanmaoa sublurida (Murrill) A. Farid \& A.R. Franck comb. nov.

MycoBank number: MB 840862; Facesoffungi number: FoF 10463

Basionym - Suillellus subluridus Murrill, Mycologia 30(5): 524 (1938).

Typification - USA. FLORIDA: Alachua Co., Gainesville, Murrill (holotype FLAS-F-15869).

Synonyms - Boletus miniato-olivaceus var. subluridus (Murrill) Singer, Mycologia 37(6): 798 (1945); Boletus subluridus (Murrill) Murrill, Mycologia 30(5): 525 (1938).

Description - Pileus 3-14 cm wide, pulvinate when young, margin entire or wrinkled, becoming convex to nearly plane at maturity, smooth, somewhat tacky when wet, bright red to ruby red when young, becoming mixed with various shades of bright red, orange red, or a peach-colored orange, especially at the margins, or sometimes turning brown entirely at maturity, sometimes becoming rimulose, revealing the context color beneath the cuticle. Hymenophore tubulose, 5-12 $\mathrm{mm}$ deep at maturity, tubes sulphur yellow, bluing on injury, fading to olive green; pores initially appearing yellow when young, stuffed, slowly and unevenly maturing to reveal red pore mouths at maturity. Stipe 5-8 $\times 1.5-3 \mathrm{~cm}$, equal, tapering upwards, or sometimes ventricose, pale yellow, especially when young, with a small network of reticulation forming isodiametric meshes in a narrow zone to $2(-5) \mathrm{mm}$ long at the apex of the stipe, but sometimes absent, especially in younger specimens, and the rest of the stipe glabrous when young with fine floccons which develop over the stipe surface as it matures, appearing smooth without a hand lens or without close inspection, at maturity these floccons giving the appearance of a stipe that is red to purplish-red, stipe surface bruising a light blue, especially when young; basal mycelium white to pale yellow. Context yellow throughout, or sometimes yellow only in the stipital context (especially so when mature), not bluing or only very weakly and slowly bluing when young, mature specimens bluing in the stipital and pileal context around the hymenophore. Taste mild, odor disagreeable, fetid, ammonia-like and slightly alliaceous.

Basidiospores (8.7)9.3-10.8(12.6) $\times(3) 3.4-4(4.6) \mu \mathrm{m}, \mathrm{n}=71, \mathrm{Q}=2.8$, boletoid thick-walled, ellipsoid-oblong to subcylindric or subfusoid, smooth, melleous. Basidia 20-25 × 6-8 $\mu \mathrm{m}$, 2- or 4spored, thin-walled, hyaline, clavate to pyriform; sterigmata 1-2 $\mu \mathrm{m}$, occasionally pigmented like pluerocystidia. Basidioles similarly sized and shaped. Pleurocystidia 30-35 × 10-15 $\mu \mathrm{m}$, pigmented a light golden brown in $\mathrm{KOH}, \mathrm{NH}_{4} \mathrm{OH}, \mathrm{H}_{2} \mathrm{O}$, and Melzer's, spores generally are clustered onto cystidia. Cheilocystidia $15-50 \times 5-10 \mu \mathrm{m}$, moderately thin-walled $(0.5 \mu \mathrm{m})$, usually pigmented like the pleurocystidia, but occasionally hyaline. Hymenophoral trama divergent. Pileipellis elements septate, terminal elements $20-65 \times 4-10 \mu \mathrm{m}$, thin-walled, cylindrical, with filiform apices that are occasionally clavate, forming an ixotrichodermium of erect elements, occasionally becoming prostrate and forming an ixosubcutis. Pileal trama composed of interwoven hyphae 3-10 $\mu \mathrm{m}$ wide, thin-walled, cylindrical.

Material examined - USA, Florida, Alachua County, Gainesville, Beneath Laurel Oak [Quercus laurifolia], 3 Jul 2020, A. Farid 1058 with R.E. O’Donovan and C. Peyer (USF 301505). 
Hillsborough County, Brandon, S of Camden Visconti pond at main entrance, 19 June 2016, A. Farid 343 (USF 288426); ibid., 26 Jun 2017, A. Farid 631 (USF 301506); ibid., 11 Jun 2018, A. Farid 805 (USF 298026); 22 Oct 2019; ibid., 11 Jun; A. Farid 1023 (USF 300104); Lithia, beneath Quercus laurifolia, 15 Jul 2020, A. Farid 1072 (USF 301508); ibid., 16 Jul 2020, A. Farid 1073 (USF 301504).

Notes - Lanmaoa G. Wu \& Zhu L. Zang is a genus of boletes which is typically distinguished by its thin hymenophore (1/3-1/5 the thickness of the pileal context at a position halfway to the pileal center), which stains blue when bruised, a light-yellow context which stains pale blue slowly when cut, and an interwoven trichodermium to subcutis pileipellis. Although no molecular diagnosis was provided in the paper describing the genus (Wu et al. 2015), the phylogenetic placement was based on the work by Wu et al. (2014). Chai et al. (2018) describe the overlapping features of Lanmaoa rubriceps N.K. Zeng \& Hui Chai with Cyanoboletus, including hymenophore size, and staining features. Lanmaoa sublurida is distinguished from similar looking boletes by the combination of its characteristic odor, a pileus that varies in reds and orange that matures to a peach-orange, sometimes brown, yellow tubes with pores that appear yellow and mature to carmine, and a light-yellow stipe with fine floccons that densely cover it at maturity.
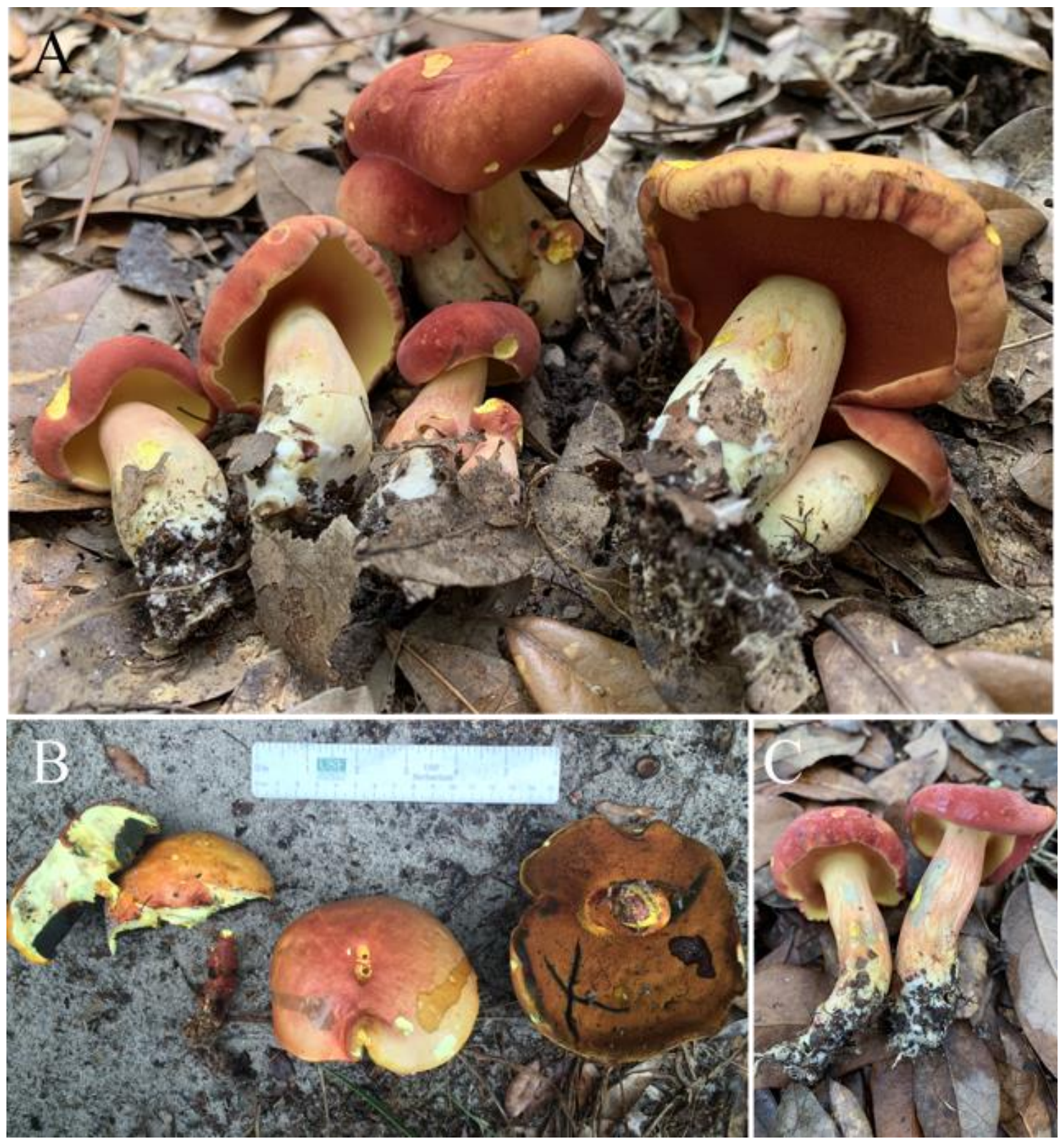

Figure 7 - Field photographs of Lanmaoa sublurida. A. Farid 1072. B. Farid 343. C. Farid 1073. Photo credits: A Farid. 


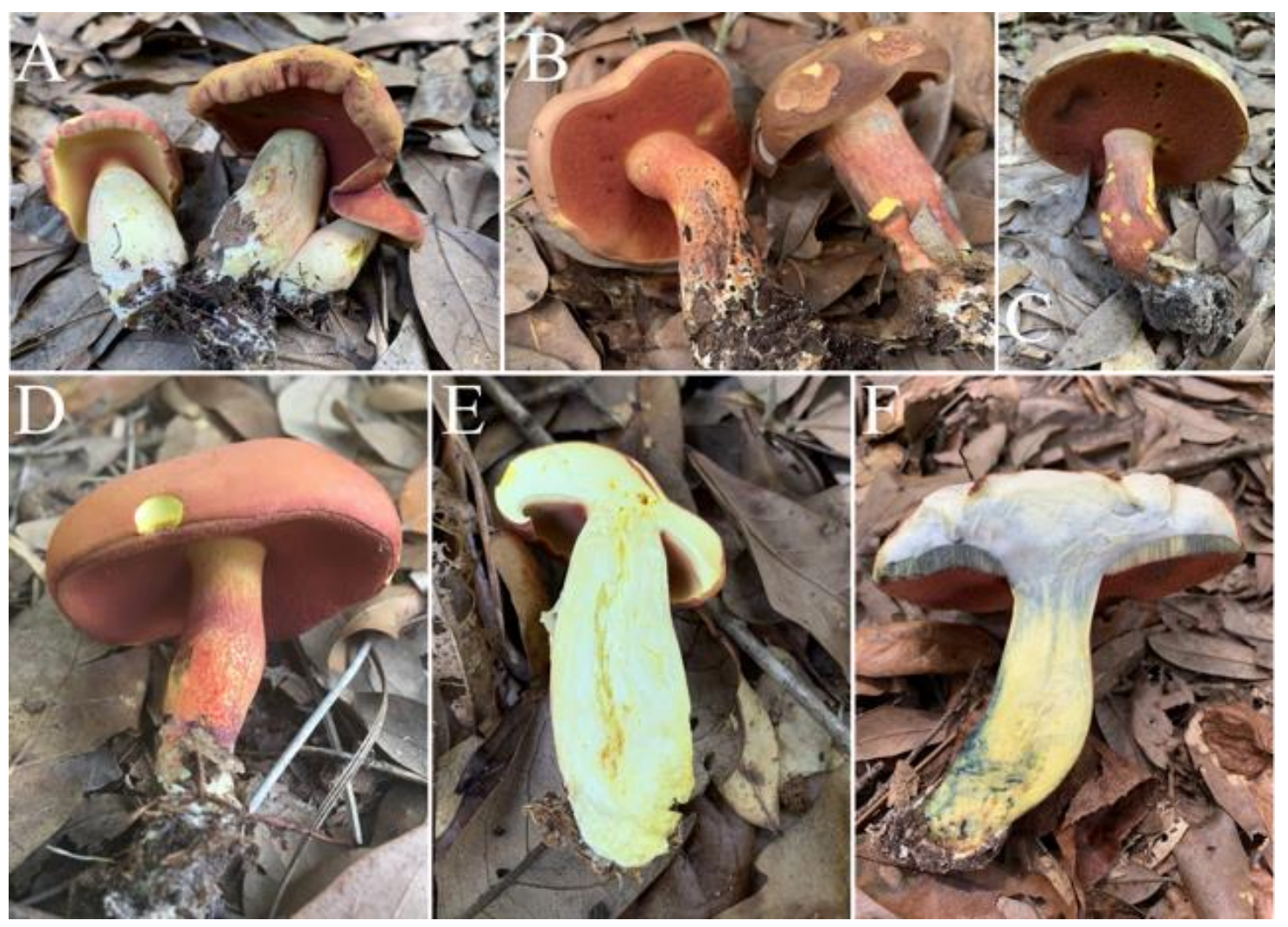

Figure 8 - Field photographs of Lanmaoa sublurida. A Farid 1072. B-C Farid 1078. D Farid 631. E-F Farid 1072, cross-section of younger (E) and older (F) specimens. Photo credits: A. Farid.

There are several species in the southeastern USA that might be confused with L. sublurida. Boletus carminiporus Bessette, Both \& Dunaway, described from Mississippi, could be confused with $L$. sublurida, although $B$. carminiporus differs in the lack of staining in the context at any stage, lacks any distinctive odor, and its stipe is usually redder, and stains olive-brown, olive-green, to oliveyellow. Lanmaoa borealis (A.H. Sm. \& Thiers) A.E. Bessette, M.E. Nuhn \& R.E. Halling is similar, but has larger spores (11-13[15] $\mu \mathrm{m}$ long) and has only been documented from the northeastern USA. The similar Boletus sensibilis Peck, found in the eastern USA, bruises similarly on the stipe, but the pore mouths are yellow (never red), the stipe develops a flush of red on the bottom half (never the purplish red that L. sublurida develops at maturity), and the context blues more readily throughout.

Xerocomellus bolinii J.A. Bolin, A.E. Bessette, A.R. Bessette, L.V. Kudzma, J.L. Frank \& A. Farid, sp. nov.

Figs 9, 10P-R

MycoBank number: MB 840863; Facesoffungi number: FoF 10462

Typification - USA, Florida: Broward County, Davie, Tree Tops Park, 27 Jan 2017, J.A. Bolin 43 (holotype USF 301496).

Etymology - The epithet bolinii honors Franklin Alexander Bolin, a biologist, naturalist and educator who for more than twenty-five years introduced thousands of students to the fields of mycology, herpetology and lepidoptery. Franklin was born and raised in Northeastern Ohio and attended Ohio State University where he earned a master's degree in both Field Zoology and Herpetology. He went on to become an Advanced Biology teacher at Grove City High School from 1963-1988. Using his unique and progressive classroom style which immersed students in "hands on learning", Bolin developed a curriculum for the entire school district known as "The Natural History of Ohio".

Diagnosis - Small to medium-sized basidiocarps with a dry, blue-staining, appressed-fibrillose to squamulose pileus with pinkish brown fibrils with white to creamy white context visible in the 
cracks. The cap context is creamy white or a mixture of creamy white and yellow, becoming yellow to orange in the stipe and rapidly stains blue when exposed. The pore surface is yellow when young, becomes dull yellow at maturity, and rapidly stains blue when bruised. The stipe has reddish brown punctae over a whitish to pale yellow ground color that darkens toward the base and staining blues when bruised. Basidiospores measure $(10-) 12-13(-14) \times 4.5-6 \mu \mathrm{m}$. It fruits on the ground with Quercus and Pinus.

Description - Pileus 4-8 cm wide, convex becoming broadly convex to nearly plane in age; pileus appressed-fibrillose to squamulose with pinkish brown fibrils and white to creamy white context visible in the cracks, dry, staining blue, sometimes slowly or weakly; margin incurved at first remaining so well into maturity, sterile, sometimes undulating, becoming conspicuously cracked with age. Hymenophore tubulose, pale yellow, becoming dull yellow in age, quickly staining dark blue; pores 1-2 per $\mathrm{mm}$, angular to irregular or slightly elongated; tubes $2-6 \mathrm{~mm}$ deep, rapidly staining blue when exposed. Stipe: $50-90 \times 8-15 \mathrm{~mm}$ wide, nearly equal or slightly tapered downward, with a pinched based, solid; surface dry, weakly longitudinally striate, with reddish brown punctae over a whitish to pale yellow ground color often with reddish tints extending from the base upward, staining blue when bruised, basal mycelium white to creamy white. Context of pileus creamy white or a mixture of creamy white and yellow becoming yellow to orange in the stipe and rapidly stains blue when exposed. Odor and taste not distinctive. Macrochemical Testing: Pileus of mature specimens showed light green fading to yellow with $\mathrm{NH}_{4} \mathrm{OH}$; younger specimens turn orange with faint green outline of stained area, eventually fading to yellow. Orange to amber, fading to brown with $\mathrm{KOH}$. Older specimens light brown and younger specimens light green with $\mathrm{FeSO}_{4}$. Context in both mature and younger specimens pale orange to $\mathrm{NH}_{4} \mathrm{OH}$, orange to amber fading to brown with the application of $\mathrm{KOH}$ and yellow with $\mathrm{FeSO}_{4}$. Cuticle stains light green, fading to yellow with $\mathrm{NH} 4 \mathrm{OH}$; younger specimens develop orange with a faint green outline that eventually fades to yellow; $\mathrm{KOH}$ produces orange to amber that fades to brown; with $\mathrm{FeS}_{4}$ mature specimens turn light brown, and younger specimens light green.

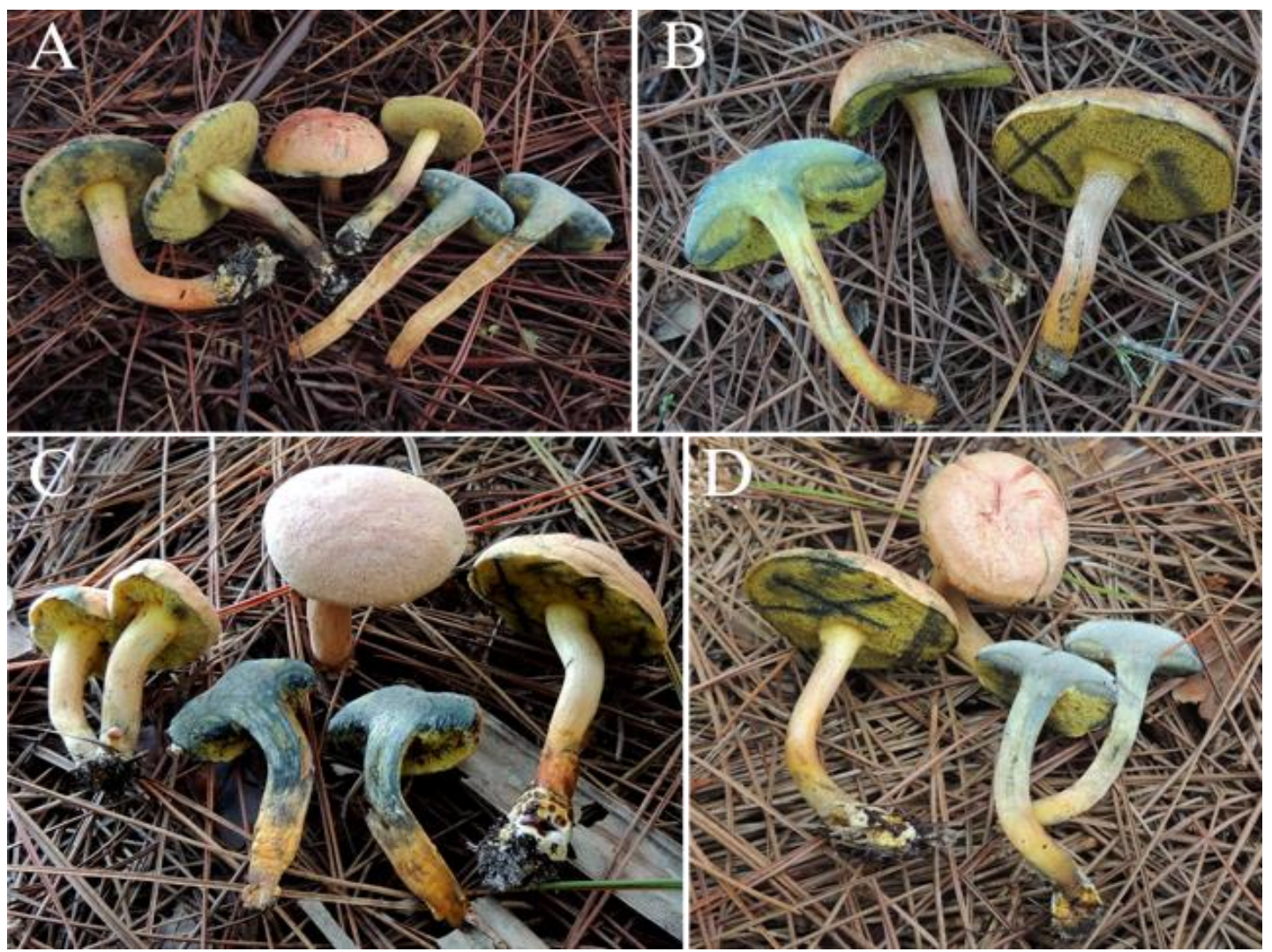

Figure 9 - Field photographs of Xerocomellus bolinii. A J.A. Bolin 238. B J.A. Bolin 274. C J.A. Bolin 232. D J.A. Bolin 208. Photo credits: J.A. Bolin. 

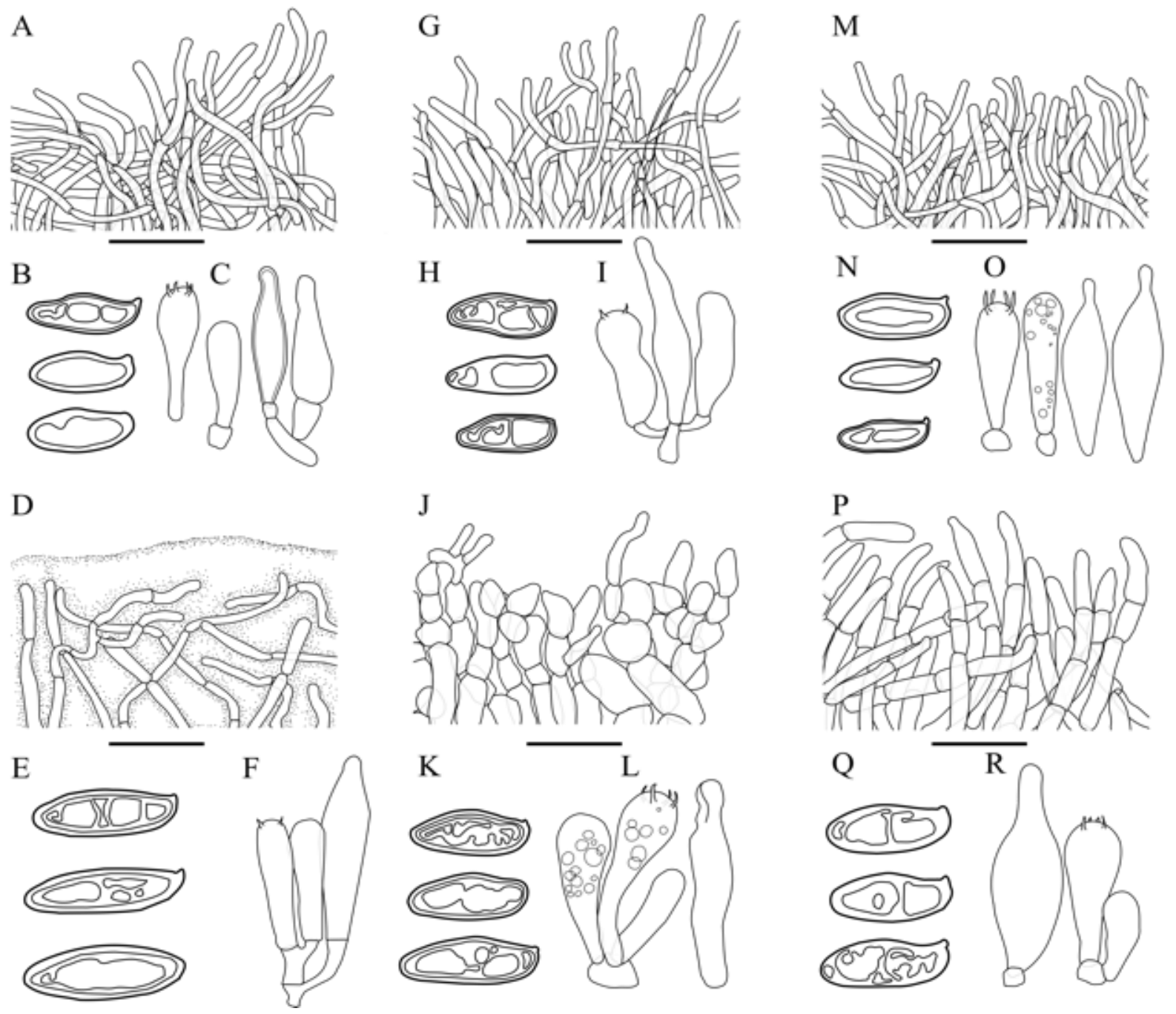

Figure 10 - Microscopic structures of the boletes from this study. A-C Cyanoboletus cyaneitinctus. D-F Aureoboletus pseudoauriporus. G-I Cyanoboletus bessettei. J-L Hemileccinum floridanum. M-O Lanmaoa sublurida. P-R Xerocomellus bolinii. A, D, G, J, M, P depict the pileipellis for each species (black bar $=50 \mu \mathrm{m}$ ), D showing a gelatinized pileipellis, B, E, H, K, N, Q depict basidiospores with guttules (black bar $=10 \mu \mathrm{m}$ ), and C, F, I, L, O, R depict basidia, basidioles, and cystidia (black bar $=20 \mu \mathrm{m}$ ), with guttules present. Drawing credits: A. Farid.

Basidiospores light brown to olive-brown in fresh deposit, $(10-) 12-13(-14) \times 4.5-6 \mu \mathrm{m}, \mathrm{n}=$ $30, \mathrm{Q}=2.40$, elliptical in face view, obscurely inequilateral in profile, thin-walled, smooth, lacking an apical pore, pale grayish yellow in KOH, dull yellow in Melzer's. Basidia 32-36 × 9-12 $\mu \mathrm{m}$, mostly clavate, occasionally cylindro-clavate, 2(4)-sterigmate, hyaline in $\mathrm{KOH}$, grayish yellow in Melzer's. Basidioles 21.5-30 × 6.5-10 $\mu \mathrm{m}$, clavate. Hymenophoral trama boletoid, with lateral elements, 5-8 $\mu \mathrm{m}$ wide, moderately divergent, hyaline in $\mathrm{KOH}$, grayish yellow in Melzer's. Pileipellis a tangled layer or repent tubular hyphae, 5-9.5 $\mu \mathrm{m}$ wide, with cylindrical, rounded to slightly inflated end cells, thin-walled, smooth, hyaline in $\mathrm{KOH}$, yellowish in Melzer's. Pileus trama hyphae loosely interwoven, 5-11 $\mu \mathrm{m}$ wide, smooth, thin-walled, hyaline in $\mathrm{KOH}$ or Melzer's. Cheilocystidia and pleurocystidia scattered, 36-48.5 ×9-11.5 $\mu \mathrm{m}$, fusoid-ventricose, smooth, thinwalled, hyaline to ochraceous in $\mathrm{KOH}$, ochraceous in Melzer's. Stipitipellis hyphae mostly parallel, slightly interwoven, 4.5-9.5 $\mu \mathrm{m}$ wide, hyaline to yellowish in $\mathrm{KOH}$ or Melzer's, with fascicles of clavate to distorted caulocystidia 34-52 $\times 9-21 \mu \mathrm{m}$, that are dull yellow to brownish yellow in $\mathrm{KOH}$ or Melzer's. Stipe trama subparallel, interwoven, 5-11.5 $\mu \mathrm{m}$ wide, hyaline to yellowish in $\mathrm{KOH}$ or Melzer's. Clamp connections absent. 
Habit, Habitat and Distribution - Solitary or scattered in sandy soil associated with Quercus and Pinus, along woodland edges, typically near saw palmetto (Serenoa repens) and/or cabbage palm (Sabal palmetto). Currently only documented from Florida. There are several images that we believe to be $X$. bolinii on the citizen science platform MushroomObserver.org (observation nos.: 430943, 412138, 293427, 289394), but no herbarium samples were made.

Specimens examined - USA, Florida, Broward County, Davie, Tree Tops Park, 14 Oct 2017, J.A. Bolin 124 (USF holotype 301494); Lake County, Lake Louisa State Park, Clermont, 13 Jun 2020, A. Farid 1047 with R.E. O’Donovan, C. Matson, and J.A. Bolin (USF 301498); Palm Beach County, Delray Beach, Morikami Museum and Japanese Gardens, 23 Sep 2017, Jason Bolin 110 (USF 300098); ibid., 17 Oct 2018, J.A. Bolin 232 (USF 300082); ibid., 12 Sep 2018, J.A. Bolin 208 (USF 301486); West Palm Beach, Okeeheelee Park, 20 Nov 2017, J.A. Bolin 133 (USF 300094); ibid., 13 Nov 2018, J.A. Bolin 238 (USF 301485); ibid., 23 Nov 2018, J.A. Bolin 274 (USF 301484).

Notes - Xerocomellus chrysenteron is similar but has a dark olive to olive-brown or greyishbrown cracked cap with exposed red to pinkish context, stains slowly or erratically greenish-blue on the hymenophore and cap context and has a more northern distribution. Xerocomellus zelleri has a dull black to blackish-brown or dark olive-brown pileus, context that is white to pale yellow that is unchanging or sometimes bluing and is reported from the Pacific Northwest south to California and into Mexico.

\section{Discussion}

\section{Contextualizing the species treated in this study}

The species treated in this paper further our understanding of the boletes, both in terms of biodiversity and systematics. Our analyses (Fig. 1) of Aureoboletus pseudoauriporus and its allies indicate that A. auriporus (Peck) Pouzar represents a species complex. Aureoboletus auriporus was described from New York as Boletus auriporus Peck (Peck 1873), with the protologue indicating a grayish-brown, sometimes tinged with red pileus color. The name has been applied widely to specimens across eastern North America, but specimens sequenced from Florida differ phylogenetically from specimens in the northeast. The pileus in A. pseudoauriporus is pinkish-tan, which differs from the grayish colors described in the protologue of Boletus auriporus. Our phylogenetic analyses placed $A$. pseudoauriporus sister to a clade containing two specimens of $A$. auriporus from Indiana and Tennesssee and A. viridiflavus from North Carolina. Three other specimens of A. auriporus (from Massachusetts, North Carolina, and Costa Rica) fell separately outside of this group (see Fig. 1). Aureoboletus viridiflavus, described from North Carolina, is a rarely documented species that is often confused for A. auriporus. In a monograph of Aureoboletus, Klofac (2010) noted most authors took A. viridiflavus as A. auriporus, but noted the subtle morphological characters separating the two species.

We have expanded our understanding of North American Cyanoboletus with the resurrection of $C$. cyaneitinctus as well as the addition of the novel species C. bessettei. Cyanoboletus cyaneitinctus is widely distributed across North America. Many previous works on North American boletes applied the European name C. pulverulentus to the North American species (Singer 1947, Bessette et al. 2017). Phylogenies consistently show significant divergence between specimens from North America and those from Europe (Gelardi et al. 2013, 2015, Braeuer et al. 2018, Fig. 1), supporting the recognition of North American material as the species $C$. cyaneitinctus. So far, the only other Cyanoboletus species known from North America now includes $C$. bessettei. Cyanoboletus bessettei is only known from the type location in South Carolina, but we expect future studies will better establish its geographical limits. Although briefly treated as a Cyanoboletus in a study by Vizzini (2014), molecular analyses by Frank et al. (2020) have since shown Xerocomellus rainisiae (Bessette \& O.K. Mill.) N. Siegel, C.F. Schwarz \& J.L. Frank is not a member of Cyanoboletus. Morphological characters that X. rainisiae shares with Xerocomellus Sutara include the pileus that becomes rimose in age, the deep red pigmentation of the basal stipital context (though less extensive than typical Xerocomellus), and the bright yellow, blue-staining hymenium. 
Similar to Chai et al. 2018, we have found Lanmaoa and Cyanoboletus to be closely related (Fig. 1) and morphologically intergrading, although Cyanoboletus tends to have dull brown colors and Lanmaoa often has bright red or yellow coloration (Wu et al. 2014, 2016, Chai et al. 2018). Cyanoboletus bessettei and C. instabilis both share the 1/3-1/5 hymenophore-to-pileal-context ratio found in Lanmaoa (and some Baorangia). Chai et al. (2018) suggested future research may consider treating Cyanoboletus and Lanmaoa as one genus, in which Cyanoboletus would have priority over Lanmaoa (Art. 11.3 of the Shenzhen Code). This is complicated by Vadthanarat et al.'s (2019) phylogenetic inference of the genus Cacaoporus Raspé \& Vadthanarat, which used the loci TEF1, $R P B 2$, atp6, and cox3 to place two named and one unnamed species of Cacaoporus sister to Cyanoboletus, while receiving no phylogenetic support for Lanmaoa and Cyanoboletus as sister genera. Due to the limited overlap of data between our dataset and Vadthanarat et al.'s dataset, sequences of Cacaoporus were not included in our final analyses. We believe the suggestion by Chai et al. (2018) to lump Lanmaoa and Cyanoboletus should be carefully re-considered in future studies of this clade as more data become available.

Hemileccinum floridanum forms a well-supported sister clade to Hemileccinum subglrabipes, the species it most closely resembles (Fig. 1). Using Singer (1947), Hemileccinum floridanum keys out to Leccinum subglabripum (Peck) Sing. (= Hemileccinum subglabripes). Insightfully, under his L. subglabripum, Singer (1947) gave a separate description for the Florida collections, which here conform to the new species $H$. floridanum. Leccinum subglapripes var. corrugatoides Singer was also described in Singer (1947), but differs from H. floridanum by a very rugose, "light brownish olive" pileus and a "light brownish olive" spore print (Singer 1947). Our collections do not possess these features, and it remains to be determined if this taxon is distinct from $H$. floridanum. Molecular analyses by Kuo \& Ortiz-Santana (2020) revised the concept of Hemileccinum to include $H$. rubropunctum, a widespread species in North America which forms tuberculate ectomycorrhizae with Quercus spp. (Smith \& Pfister 2009). Roots beneath several collections of Hemileccinum floridanum were examined for tuberculate ectomycorrhizae, but none were located. Thus far $H$. rubropunctum is unique in its ability to form tuberculate ectomycorrhizae within the Boletaceae, though other Boletales are capable of this (e.g. Suillus and Rhizopogon).

Xerocomellus bolinii is here placed as sister to a clade of Eurasian species, one of which has been considered part of the genus Rheubarbariboletus Vizzini, Simonini \& Gelardi. Similar to Frank et al. (2020), our phylogenetic analysis finds Heliogaster Orihara \& K. Iwase and Rheubarbariboletus embedded in the Xerocomellus lineage and Nigroboletus to be sister to this broadly defined Xerocomellus lineage. Vizzini (2015) cited the ITS-based phylogeny in Gelardi et al. (2013) and unpublished data as the molecular basis for establishing Rheubarbariboletus, differing from Xerocomellus by its smooth, non-striate and non-truncate spores, smooth or finely incrusted pileipellis, congophilous plaques on the hyphal surface, tapered and rooting stipe base, the bright yellow-ochraceous to orange-rhubarb and unchangeable context in the stipe base, and the dark bluegreen blackish reaction with $\mathrm{FeSO}_{4}$ on the pileus surface and the base of the stipe context. Xerocomellus bolinii, while sharing the non-bluing basal stipital context, smooth, non-truncate spores, and smooth pileipellis of Rheubarbariboletus, differs in its reaction to the application of $\mathrm{FeSO}_{4}$ to the context by only turning light brown to light green (in old and young specimens, respectively), and by lacking a rooting stipe. In light of these molecular and morphological data, it seems best to include Heliogaster and Rheubarbariboletus within Xerocomellus at this time.

We follow Bozok et al. (2019) in recognizing Exsudoporus as a genus separate from Butyriboletus. Wu et al. (2016) treated the genus as a synonym of Butyriboletus, citing the reticulation and interwoven trichodermium to subcutis pileipellis as shared characters with the genus Butyriboletus. Bozok et al. (2019) reported on the positive amyloid reaction in the stipe tissues of $E$. permagnificus, a feature not shared with Butyriboletus. Our observations of E. floridanus show that the stipe base context exhibits a dextrinoid reaction in the stipe base (pers. obs.). Also, Exsudoporus species have pores that are discolorous with the tubes, and the basidiomes bruise blue much darker and heavier than Butyriboletus species. The guttation on the pores is regularly found, especially in younger specimens of Exsudoporus species, and is a useful distinguishing character. Wu et al. (2016) 
reported species which were sister to the clade containing Exsudoporus and Butyriboletus, but these species remain undescribed. Additional analyses and thorough morphological comparison of those undescribed species might justify a broader concept of Butyriboletus, however until those analyses are produced, retaining the genus Exsudoporus is preferred.

\section{Conclusions}

This paper updates our understanding of the boletes in southeastern USA. Four novel species are described, as well as resurrecting and applying the name Cyanoboletus cyaneitinctus to the Cyanoboletus species widespread across North America. Our molecular analyses (Fig. 1) provide a DNA-based approach to aid morphological classification of these boletes and to better understand the distribution of these species. Our analyses also support the many genera found in recent Boletaceae phylogenetic reconstructions (Wu et al. 2014, 2016). By analyzing the protein-coding loci (RPB1, RPB2, TEF1) from a collection of Butyriboletus floridanus on GenBank, we have also confirmed a disjunct distribution for this tropical species. Inclusion of additional data from the epitype of Pulchroboletus rubricitrinus also lends the specimen to broader phylogenetic analyses. We also provide sequences of western USA Xerocomellus, which will aid future bolete phylogenetic reconstructions, as many species of Xerocomellus from North America lack protein coding loci.

This paper increases the knowledge of biodiversity present in the region. The potential for robust future studies is impeded by a lack of baseline knowledge of biodiversity. As molecular phylogenetic analyses continuously update the taxonomy of our classifications of the boletes, the need for further investigations into the boletes of the southeastern USA becomes readily apparent. Important aspects, such as morphological traits, host-specificity and geographic distribution, have been shown to be incredibly important with regards to boletes. Species-level concepts which were once broadly defined and applied widely across eastern North America have been shown to encompass several species, sometimes with clear morphological characters to distinguish them, as well as cryptic species in which geography seems to play a key role. Increasing and updating our understanding of boletes allows researchers to obtain richer species-level sequence-based identifications in environmental studies (Hibbett et al. 2011, Truong et al. 2017, Xu 2016), which is important for ecological studies, and paramount to better understanding threatened ecosystems in the southeastern USA. Macrofungal species have shown the potential for introduction and spread, e.g. Favolaschia, Clathrus archeri, Perenniporia ochroleuca, and the bolete Aureoboletus projectellus (Desprez-Loustau et al. 2007, Pringle et al. 2009, Vizzini et al. 2009, Wrzosek et al. 2017, Banasiak et al. 2019). Considering many species of boletes in the southeastern USA are geographically restricted, there is the potential that exotic mycorrhizal fungi may outcompete these endemic species.

\section{Acknowledgements}

This work was funded by the Cooley and Lakela funds at USF. The authors would like to thank the herbaria staff and faculty who assisted in facilitating loans for this study. We would also like to thank Hillsborough County Conservation and Environmental Lands Management, the Southwest Florida Water Management District, the Florida Park Service's Bureau of Natural \& Cultural Resources, and the Everglades National Park for granting us research permits that enabled us to sample fungi from their respective parks and are grateful to the park managers and staff for their support and assistance. We would also like to thank Jonathan Frank for sending USF specimens of western Xerocomellus for our phylogenetic analyses, and Clare Dennison for her help at the SEM lab at USF.

\section{References}

Banasiak Ł, Pietras M, Wrzosek M, Okrasińska A et al. 2019 - Aureoboletus projectellus (Fungi, Boletales) - an American bolete rapidly spreading in Europe as a new model species for studying expansion of macrofungi. Fungal Ecology 39, 94-9. 
Baroni TJ. 1998 - Boletus aurantiosplendens sp. nov. from the southern Appalachian Mountains with notes on Pulveroboletus auriflammeus, Pulveroboletus melleouluteus and Boletus auripes. Bull Buff Soc Nat Sci 36, 245-255.

Baroni TJ. 2017 - Mushrooms of the northeastern United States and eastern Canada. Timber Press. $600 \mathrm{p}$.

Baroni TJ, Bessette AE, Roody WC. 1998 - Boletus patrioticus - A new species from the eastern United States. Bull Buff Soc nat Sci 36, 265-268.

Berkeley MJ, Curtis MA. 1853 - Centuries of North American Fungi. Annals and Magazine of Natural History 12(72), 417-435.

Bessette AE, Bessette AR, Roody WC. 2000 - North American Boletes: a color guide to the fleshy pored mushrooms. Syracuse University Press. 146 p.

Bessette AE, Roody WC, Bessette AR. 2017 - Boletes of Eastern North America. Syracuse University Press, Syracuse.

Both EE. 1993 - The Boletes of North America: A compendium. Buffalo Society of Natural Sciences, New York.

Both EE. 1998 - New taxa of boletes and two boletes with identity problems. Bulletin of the Buffalo Society of Natural Sciences, 36, 215-232.

Both EE, Ortiz-Santana B. 2010 - Clinton, Peck and Frost: The dawn of North American boletology. Bulletin of the Buffalo Society of Natural Sciences, 39, 11-28.

Bozok F, Assyov B, Taşkin H. 2019 - First records of Exsudoporus permagnificus and Pulchroboletus roseoalbidus (Boletales) in association with non-native Fagaceae, with taxonomic remarks. Phytologia Balcanica 25(1), 13-27.

Braeuer S, Goessler W, Kameník J, Konvalinková T et al. 2018 - Arsenic hyperaccumulation and speciation in the edible ink stain bolete (Cyanoboletus pulverulentus). Food chemistry 242, 225-31.

Castellano MA, Elliott TF, Truong C, Séné O et al. 2016 - Kombocles bakaiana gen. sp. nov. (Boletaceae), a new sequestrate fungus from Cameroon. IMA fungus 7(2), 239.

Chai H, Liang ZQ, Jiang S, Fu XL, Zeng NK. 2018 -Lanmaoa rubriceps, a new bolete from tropical China. Phytotaxa 347(1), 71-80.

Coker WC, Beers AH. 1943 - The boleti of North Carolina. Dover, New York. (1971 reprint.)

Crous PW, Wingfield MJ, Lombard L, Roets F et al. 2019 - Fungal Planet description sheets: 9511041. Persoonia: Molecular Phylogeny and Evolution of Fungi 43, 223-425.

Darriba D, Taboada GL, Doallo R, Posada D. 2012 -jModelTest 2: more models, new heuristics and parallel computing. Nature methods 9(8), 772.

Desprez-Loustau ML, Robin C, Buee M, Courtecuisse R et al. 2007 - The fungal dimension of biological invasions. Trends in Ecology \& Evolution 22(9), 472-80.

Farid A, Franck AR, Bolin J, Garey JR. 2020 - Expansion of the genus Imleria in North America to include Imleria floridana, sp. nov., and Imleria pallida, comb. nov. Mycologia 112(2), 42337.

Farid A, Franck AR, Garey JR. 2017 - Boletus rubricitrinus belongs in Pulchroboletus (Boletaceae). Czech Mycology 69(2), 143-162.

Farid A, Gelardi M, Angelini C, Franck AR et al. 2018 - Phylloporus and Phylloboletellus are no longer alone: Phylloporopsis gen. nov. (Boletaceae), a new smooth-spored lamellate genus to accommodate the American species Phylloporus boletinoides. Fungal Systematics and Evolution 2(1), 341-359.

Frank J, Bessette AR, Bessette AE. 2017 -Alessioporus rubriflavus (Boletaceae), a new species from the eastern United States. North American Fungi 28 12, 1-8.

Frank JL, Siegel N, Schwarz CF, Araki B, Vellinga EC. 2020 - Xerocomellus (Boletaceae) in western North America. Fungal Systematics and Evolution 5(1), 265-288.

Felsenstein J, Felenstein J. 2004 - Inferring phylogenies. Sinauer associates, Sunderland, Massachussetts. 
Gelardi M, Simonini G, Ercole E, Davoli P, Vizzini A. 2015 - Cupreoboletus (Boletaceae, Boletineae), a new monotypic genus segregated from Boletus sect. Luridi to reassign the Mediterranean species B. poikilochromus. Mycologia 107(6), 1254-1269.

Gelardi M, Vizzini A, Ercole E, Voyron S et al. 2013 - Boletus sinopulverulentus, a new species from Shaanxi Province (central China) and notes on Boletus and Xerocomus. Sydowia 65(1), 45-57.

Gardes M, Bruns TD. 1993 - ITS primers with enhanced specificity for basidiomycetes-application to the identification of mycorrhizae and rusts. Molecular ecology 2(2), 113-138.

Grand LF. 1970a - Notes on North Carolina Boletes. I. Species of Boletellus, Phylloporus, Strobilomyces, Tylopilus, and Xanthoconium. Journal of the Elisha Mitchell Scientific Society 1, 49-56.

Grand LF. 1970b - Notes on North Carolina boletes. II. Species of Gyrodon, Gyroporus, Xerocomus, and Leccinum. Journal of the Elisha Mitchell Scientific Society 1, 57-61.

Grand LF. 1970c - Notes on North Carolina boletes. III. Species of Suillus. Journal of the Elisha Mitchell Scientific Society 1, 209-213.

Guindon S, Gascuel O. 2003 - A simple, fast, and accurate algorithm to estimate large phylogenies by maximum likelihood. Systeatic biology 52(5), 696-704.

Halling RE. 1983 - Boletes described by Charles C. Frost. Mycologia 75(1), 70-92.

Halling RE. 1986 - An annotated index to species and infraspecific taxa of Agaricales and Boletales described by William A. Murrill. Memoirs of the New York Botanical Garden, New York.

Halling RE, Nuhn M, Fechner NA, Osmundson TW et al. 2012 - Sutorius: a new genus for Boletus eximius. Mycologia 104(4), 951-961.

Hibbett DS, Ohman A, Glotzer D, Nuhn M et al. 2011 - Progress in molecular and morphological taxon discovery in Fungi and options for formal classification of environmental sequences. Fungal biology reviews 25(1), 38-47.

Katoh K, Standley DM. 2013 - MAFFT multiple sequence alignment software version 7: improvements in performance and usability. Molecular biology and evolution 30(4), 772-80.

Klofac W. 2010 - The genus Aureoboletus, a world-wide survey. a contribution to a monographic treatment. Österreichische Zeitschrift für Pilzkunde 2010(19), 133-174.

Kuo M, Ortiz-Santana B. 2020 - Revision of leccinoid fungi, with emphasis on North American taxa, based on molecular and morphological data. Mycologia 112(1), 197-211.

Matheny PB, Liu YJ, Ammirati JF, Hall BD. 2002 - Using RPB1 sequences to improve phylogenetic inference among mushrooms (Inocybe, Agaricales). American Journal of Botany 89(4), 688698.

Miller MA, Pfeiffer W, Schwartz T. 2010 - Creating the CIPRES Science Gateway for inference of large phylogenetic trees. In: 2010 gateway computing environments workshop (GCE). IEEE. New Orleans.

Murrill WA. 1909 - The Boletaceae of North America - I. Mycologia 1(1), 4-18.

Murrill WA. 1948 - Florida Boletes. Lloydia 11, 21-35.

Nuhn ME, Binder M, Taylor AF, Halling RE, Hibbett DS. 2013 - Phylogenetic overview of the Boletineae. Fungal Biology 117(7-8), 479-511.

Ortiz-Santana B, Bessette AE, McConnell OL. 2016 - Boletus durhamensis sp. nov. from North Carolina. Mycotaxon 131(3),703-715.

Ortiz-Santana B, Roody WC, Both EE. 2009 - A new arenicolous Boletus from the Gulf Coast of northern Florida. Mycotaxon 107, 243-247.

Peck CH. 1873 - Report of the Botanist (1869). Annual Report on the New York State Museum of Natural History 23, 27-135.

Peck CH. 1889 - Boleti of the United States. Bulletin of the New York State Museum 2(8). 73-166.

Pringle A, Adams RI, Cross HB, Bruns TD. 2009 - The ectomycorrhizal fungus Amanita phalloides was introduced and is expanding its range on the west coast of North America. Molecular Ecology 18(5), 817-833. 
R Core Team. 2017 - R: A language and environment for statistical computing. R Foundation for Statistical Computing,Vienna, Austria. URL https://www.R-project.org/.

Rambaut A. 2007 - FigTree, a graphical viewer of phylogenetic trees. Institute of Evolutionary Biololgy, University of Edinburgh.

Rambaut A, Drummond AJ, Xie D, Baele G, Suchard MA. 2018 - Posterior summarization in Bayesian phylogenetics using Tracer 1.7. Systematic biology 67(5), 901-904.

Ronquist F, Teslenko M, Van Der Mark P, Ayres DL et al. 2012 - MrBayes 3.2: efficient Bayesian phylogenetic inference and model choice across a large model space. Systematic biology 61(3), 539-542.

von Schweinitz LD. 1822 - Synopsis fungorum Carolinae superioris secundum observationes Ludovici Davidis de Schweinitz. Leipzig: Johann Ambrosius Barth.

Singer R. 1945a - The Boletineae of Florida with notes on extralimital species I. The Strobilomycetaceae. Farlowia 2, 97-141.

Singer R. 1945b - The Boletineae of Florida with notes on extralimital species. II. The Boletaceae. Farlowia 2, 223-303

Singer R. 1947 - The Boletoideae of Florida with Notes on Extralimital Species III. The American Midland Naturalist 37(1), 1-135.

Singer R. 1986 - The Agaricales in modern taxonomy. 4 edn. Vaduz, Germany: Koeltz. 726 p.

Singer R, Williams R. 1992 - Some boletes from Florida. Mycologia 84(5), 724-728.

Smith AH, Thiers HD. 1971 - Boletes of Michigan. University of Michigan Press, Ann Arbor.

Smith ME, Amses KR, Elliott TF, Obase K et al. 2015 - New sequestrate fungi from Guyana: Jimtrappea guyanensis gen. sp. nov., Castellanea pakaraimophila gen. sp. nov., and Costatisporus cyanescens gen. sp. nov. (Boletaceae, Boletales). IMA fungus 6(2), 297-317.

Smith ME, Pfister DH. 2009 - Tuberculate ectomycorrhizae of angiosperms: the interaction between Boletus rubropunctus (Boletaceae) and Quercus species (Fagaceae) in the United States and Mexico. American Journal of Botany, 96(9), 1665-1675.

Stamatakis A. 2014 - RAxML version 8: a tool for phylogenetic analysis and post-analysis of large phylogenies. Bioinformatics, 30(9), 1312-1313.

Šutara J. 2008 - Xerocomus s. 1. in the light of the present state of knowledge. Czech Mycol 60(1): $29-62$.

Thiers HD. 1963 - The bolete flora of the Gulf coastal plain. I. The Strobilomyceteae. Journal of the Elisha Mitchell Scientific Society, 79(1), 32-41.

Truong C, Mujic AB, Healy R, Kuhar F et al. 2017 - How to know the fungi: combining field inventories and DNA-barcoding to document fungal diversity. New Phytologist 214(3), 9139.

Vizzini A. 2014 - Nomenclatural novelties. Index Fungorum 176, 1.

Vizzini A. 2015 - Nomenclatural novelties. Index Fungorum 244, 1.

Vizzini A, Zotti M, Mello A. 2009 - Alien fungal species distribution: the study case of Favolaschia calocera. Biological invasions 11(2), 417-429.

Vadthanarat S, Lumyong S, Raspé O. 2019 - Cacaoporus, a new Boletaceae genus, with two new species from Thailand. MycoKeys 54, 1-29.

Vadthanarat S, Raspé O, Lumyong S. 2018 - Phylogenetic affinities of the sequestrate genus Rhodactina (Boletaceae), with a new species, $R$. rostratispora from Thailand. MycoKeys 2018(29), 63-80.

Vilgalys R, Hester M. 1990 - Rapid genetic identification and mapping of enzymatically amplified ribosomal DNA from several Cryptococcus species. Journal of bacteriology 172(8), 42384246.

Walter T. 1788 - Flora Caroliniana. Flora caroliniana. J. Fraser, London. 263 p.

Weber GF. 1961 - William Alphonso Murrill. Mycologia 53(6), 543-557.

White TJ, Bruns T, Lee SJ, Taylor J. 1990 - Amplification and direct sequencing of fungal ribosomal RNA genes for phylogenetics. PCR protocols: a guide to methods and applications 18(1), 315322. 
Wrzosek M, Motiejūnaitė J, Kasparavičius J, Wilk M et al. 2017 - The progressive spread of Aureoboletus projectellus (Fungi, Basidiomycota) in Europe. Fungal Ecology 27:134-136.

Wu G, Lee SM, Horak E, Yang ZL. 2018 - Spongispora temasekensis, a new boletoid genus and species from Singapore. Mycologia 110(5), 919-929.

Wu G, Zhao K, Li YC, Zeng NK et al. 2016 - Four new genera of the fungal family Boletaceae. Fungal Diversity 81(1), 1-24.

Wu G, Feng B, Xu J, Zhu XT et al. 2014 - Molecular phylogenetic analyses redefine seven major clades and reveal 22 new generic clades in the fungal family Boletaceae. Fungal Diversity 69(1) 93-115.

Xu J. 2016 - Fungal DNA barcoding. Genome 59(11) 913-932.

Yang ZL, Trappe JM, Binder M, Sanmee R et al. 2006 - The sequestrate genus Rhodactina (Basidiomycota, Boletales) in northern Thailand. Mycotax on 96, 133-140.

Zhang M, Li TH. 2018 - Erythrophylloporus (Boletaceae, Boletales), a new genus inferred from morphological and molecular data from subtropical and tropical China. Mycosystema 37(9), 1111-1126.

Zhao K, Wu G, Yang ZL. 2014 - A new genus, Rubroboletus, to accommodate Boletus sinicus and its allies. Phytotaxa 188(2), 61-77.

Supplementary Table 1 GenBank accession number and other information of sequences used in phylogenetic analyses in this study. Sequences in bold were generated in this study.

\begin{tabular}{|c|c|c|c|c|c|c|}
\hline \multirow[t]{2}{*}{ Species } & \multirow{2}{*}{$\begin{array}{l}\text { GenBank } \\
\text { voucher }\end{array}$} & \multicolumn{5}{|c|}{ Locus } \\
\hline & & ITS & $28 S$ & RPBI & $R P B 2$ & TEF \\
\hline $\begin{array}{l}\text { Alessioporus } \\
\text { ichnusanus }\end{array}$ & AMB 12756 & KJ729491 & KJ729504 & - & - & KJ729513 \\
\hline $\begin{array}{l}\text { Alessioporus } \\
\text { ichnusanus }\end{array}$ & MG420a & KJ729496 & KJ729509 & - & - & - \\
\hline $\begin{array}{l}\text { Alessioporus } \\
\text { rubriflavus }\end{array}$ & ARB1356 & KU736957 & MH656696 & - & - & - \\
\hline $\begin{array}{l}\text { Alessioporus } \\
\text { rubriflavus }\end{array}$ & JLF2561 & KU736958 & KC812306 & - & - & - \\
\hline $\begin{array}{l}\text { Aureoboletus } \\
\text { auriflammeus }\end{array}$ & $\begin{array}{l}\text { CFMR BOS } \\
699\end{array}$ & - & MK601706 & - & MK766269 & MK721060 \\
\hline $\begin{array}{l}\text { Aureoboletus } \\
\text { auriporus }\end{array}$ & 3597 & - & DQ534636 & - & - & - \\
\hline $\begin{array}{l}\text { Aureoboletus } \\
\text { auriporus }\end{array}$ & AB11 & MH796985 & - & - & - & - \\
\hline $\begin{array}{l}\text { Aureoboletus } \\
\text { auriporus }\end{array}$ & $\mathrm{AB} 12$ & MH796989 & - & - & - & - \\
\hline $\begin{array}{l}\text { Aureoboletus } \\
\text { auriporus }\end{array}$ & BDCR0431 & - & HQ161871 & HQ161840 & - & - \\
\hline $\begin{array}{l}\text { Aureoboletus } \\
\text { auriporus }\end{array}$ & FLAS F 60185 & MH796985 & - & - & - & - \\
\hline $\begin{array}{l}\text { Aureoboletus } \\
\text { auriporus }\end{array}$ & FLAS F 60914 & MH211684 & - & - & - & - \\
\hline $\begin{array}{l}\text { Aureoboletus } \\
\text { auriporus }\end{array}$ & FLAS F 60985 & MH016931 & - & - & - & - \\
\hline $\begin{array}{l}\text { Aureoboletus } \\
\text { auriporus }\end{array}$ & MAC09 TENN & MF755267 & - & - & - & - \\
\hline $\begin{array}{l}\text { Aureoboletus } \\
\text { auriporus }\end{array}$ & $\begin{array}{l}\text { S D Russell } \\
\text { MycoMap } \\
6611\end{array}$ & MK560093 & - & - & - & - \\
\hline $\begin{array}{l}\text { Aureoboletus } \\
\text { catenarius }\end{array}$ & GDGM45142 & - & MN204514 & - & - & - \\
\hline $\begin{array}{l}\text { Aureoboletus } \\
\text { catenarius }\end{array}$ & HKAS54463 & - & KT990509 & KT990890 & KT990348 & KT990710 \\
\hline
\end{tabular}


Supplementary Table 1 Continued.

\begin{tabular}{|c|c|c|c|c|c|c|}
\hline \multirow[t]{2}{*}{ Species } & \multirow{2}{*}{$\begin{array}{l}\begin{array}{l}\text { GenBank } \\
\text { voucher }\end{array} \\
\end{array}$} & \multicolumn{5}{|c|}{ Locus } \\
\hline & & ITS & $28 S$ & RPBI & RPB2 & TEF \\
\hline $\begin{array}{l}\text { Aureoboletus } \\
\text { catenarius }\end{array}$ & HKAS54467 & - & KT990510 & - & KT990349 & KT990711 \\
\hline $\begin{array}{l}\text { Aureoboletus } \\
\text { clavatus }\end{array}$ & GDGM42962 & - & KR052045 & KR052056 & - & - \\
\hline $\begin{array}{l}\text { Aureoboletus } \\
\text { clavatus }\end{array}$ & GDGM42963 & - & KR052046 & KR052057 & - & KR052054 \\
\hline $\begin{array}{l}\text { Aureoboletus } \\
\text { clavatus }\end{array}$ & GDGM42984 & - & KR052047 & - & - & KR052055 \\
\hline $\begin{array}{l}\text { Aureoboletus } \\
\text { clavatus }\end{array}$ & HKAS59802 & - & KR052044 & - & - & KR052053 \\
\hline $\begin{array}{l}\text { Aureoboletus } \\
\text { duplicatoporus }\end{array}$ & HKAS63009 & - & KT990511 & KT990891 & KT990350 & KT990712 \\
\hline $\begin{array}{l}\text { Aureoboletus } \\
\text { duplicatoporus }\end{array}$ & HKAS83115 & - & KT990512 & КT990892 & KT990351 & KT990713 \\
\hline $\begin{array}{l}\text { Aureoboletus } \\
\text { gentilis }\end{array}$ & ADK4865 & - & - & - & KT823994 & KT824027 \\
\hline $\begin{array}{l}\text { Aureoboletus } \\
\text { gentilis }\end{array}$ & MG372a & - & KF112344 & KF112557 & KF112741 & KF134014 \\
\hline $\begin{array}{l}\text { Aureoboletus } \\
\text { gentilis }\end{array}$ & Pug1 & - & DQ534635 & - & - & KF030399 \\
\hline $\begin{array}{l}\text { Aureoboletus } \\
\text { griseorufescens }\end{array}$ & GDGM28490 & - & MH670278 & - & MH700241 & - \\
\hline $\begin{array}{l}\text { Aureoboletus } \\
\text { griseorufescens }\end{array}$ & ZM131 & - & MH670279 & MH700220 & MH700242 & - \\
\hline $\begin{array}{l}\text { Aureoboletus } \\
\text { innixus }\end{array}$ & $\begin{array}{l}\text { CFMR BOS } \\
544\end{array}$ & - & MK601707 & - & MK766270 & MK721061 \\
\hline $\begin{array}{l}\text { Aureoboletus } \\
\text { innixus }\end{array}$ & MB03 104 & - & KF030239 & - & - & KF030400 \\
\hline $\begin{array}{l}\text { Aureoboletus } \\
\text { mirabilis }\end{array}$ & HKAS57776 & - & KF112360 & KF112624 & KF112743 & KF112229 \\
\hline $\begin{array}{l}\text { Aureoboletus } \\
\text { mirabilis }\end{array}$ & REH9765 & - & KP327661 & - & - & KP327709 \\
\hline $\begin{array}{l}\text { Aureoboletus } \\
\text { moravicus }\end{array}$ & MG374a & - & KF112421 & KF112559 & KF112745 & KF112232 \\
\hline $\begin{array}{l}\text { Aureoboletus } \\
\text { moravicus }\end{array}$ & VDKO1120 & - & - & - & MG212615 & MG212573 \\
\hline $\begin{array}{l}\text { Aureoboletus } \\
\text { moravicus fluteus }\end{array}$ & $\begin{array}{l}\text { PARMA } 1544 \\
11\end{array}$ & KJ676960 & KJ676958 & - & - & KJ676959 \\
\hline $\begin{array}{l}\text { Aureoboletus } \\
\text { nephrosporus }\end{array}$ & HKAS67931 & - & KT990516 & KT990895 & KT990357 & КT990720 \\
\hline $\begin{array}{l}\text { Aureoboletus } \\
\text { nephrosporus }\end{array}$ & HKAS74929 & - & КT990517 & КТ990896 & КT990358 & КТ990721 \\
\hline $\begin{array}{l}\text { Aureoboletus } \\
\text { projectellus }\end{array}$ & $\begin{array}{l}\text { MICH KUO } \\
09111014\end{array}$ & - & MK601708 & - & MK766271 & MK721062 \\
\hline $\begin{array}{l}\text { Aureoboletus } \\
\text { projectellus }\end{array}$ & NYBG13392 & - & KP327622 & - & - & KP327675 \\
\hline $\begin{array}{l}\text { Aureoboletus } \\
\text { quercus }\end{array}$ & $\begin{array}{l}\text { spinosae } \\
\text { GDGM43755 }\end{array}$ & KY039954 & KY039967 & KY039963 & KY039958 & - \\
\hline $\begin{array}{l}\text { Aureoboletus } \\
\text { quercus }\end{array}$ & $\begin{array}{l}\text { spinosae } \\
\text { GDGM43758 }\end{array}$ & KY039955 & KY039968 & KY039964 & KY039959 & - \\
\hline $\begin{array}{l}\text { Aureoboletus } \\
\text { quercus }\end{array}$ & $\begin{array}{l}\text { spinosae } \\
\text { GDGM43786 }\end{array}$ & - & KY039969 & KY039965 & KY039960 & - \\
\hline $\begin{array}{l}\text { Aureoboletus } \\
\text { raphanaceus }\end{array}$ & GDGM44832 & - & MH670268 & MH700218 & MH700236 & MH700194 \\
\hline
\end{tabular}


Supplementary Table 1 Continued.

\begin{tabular}{|c|c|c|c|c|c|c|}
\hline \multirow[t]{2}{*}{ Species } & \multirow{2}{*}{$\begin{array}{l}\text { GenBank } \\
\text { voucher }\end{array}$} & \multicolumn{5}{|c|}{ Locus } \\
\hline & & ITS & $28 S$ & $R P B 1$ & RPB2 & TEF \\
\hline $\begin{array}{l}\text { Aureoboletus } \\
\text { raphanaceus }\end{array}$ & GDGM52543 & - & MH670271 & - & MH700237 & - \\
\hline $\begin{array}{l}\text { Aureoboletus } \\
\text { raphanaceus }\end{array}$ & GDGM52590 & - & MH670272 & MH700219 & MH700238 & MH700193 \\
\hline $\begin{array}{l}\text { Aureoboletus } \\
\text { roxanae }\end{array}$ & $\begin{array}{l}\text { CFMR BOS } \\
698\end{array}$ & - & MK601709 & - & MK766272 & MK721063 \\
\hline $\begin{array}{l}\text { Aureoboletus } \\
\text { roxanae }\end{array}$ & DS626 07 & - & KF030311 & KF030381 & - & KF030402 \\
\hline $\begin{array}{l}\text { Aureoboletus } \\
\text { russellii }\end{array}$ & $\begin{array}{l}\text { CFMR BOS } \\
716\end{array}$ & - & MK601710 & - & MK766273 & MK721064 \\
\hline $\begin{array}{l}\text { Aureoboletus } \\
\text { singeri }\end{array}$ & $\begin{array}{l}\text { CFMR BZ } \\
2395 \text { BOS } 468\end{array}$ & MN250221 & MK601711 & - & MK766274 & MK721065 \\
\hline Aureoboletus sp & GDGM44829 & - & KY039970 & - & KY039961 & - \\
\hline $\begin{array}{l}\text { Aureoboletus } \\
\text { tenuis }\end{array}$ & GDGM42601 & KF265358 & KF534789 & - & KT291754 & KT291745 \\
\hline $\begin{array}{l}\text { Aureoboletus } \\
\text { tenuis }\end{array}$ & HKAS75104 & - & KT990518 & KT990897 & KT990359 & KT990722 \\
\hline $\begin{array}{l}\text { Aureoboletus } \\
\text { thibetanus }\end{array}$ & HKAS57692 & - & KT990524 & KT990901 & KT990365 & KT990728 \\
\hline $\begin{array}{l}\text { Aureoboletus } \\
\text { thibetanus }\end{array}$ & HKAS76655 & - & KF112420 & KF112626 & KF112752 & KF112236 \\
\hline $\begin{array}{l}\text { Aureoboletus } \\
\text { thibetanus }\end{array}$ & HKAS89494 & - & KT990525 & KT990902 & KT990366 & KT990729 \\
\hline $\begin{array}{l}\text { Aureoboletus } \\
\text { tomentosus }\end{array}$ & HKAS59694 & - & KT990513 & KT990893 & KT990352 & КT990714 \\
\hline $\begin{array}{l}\text { Aureoboletus } \\
\text { tomentosus }\end{array}$ & HKAS80485 & - & - & KT990894 & KT990353 & KT990715 \\
\hline $\begin{array}{l}\text { Aureoboletus } \\
\text { viridiflavus }\end{array}$ & - & AY612805 & - & - & - & - \\
\hline $\begin{array}{l}\text { Aureoboletus } \\
\text { viscidipes }\end{array}$ & HKAS77103 & - & KT990519 & - & KT990360 & KT990723 \\
\hline $\begin{array}{l}\text { Aureoboletus } \\
\text { viscosus }\end{array}$ & OR0361 & - & - & - & MH614751 & MH614703 \\
\hline $\begin{array}{l}\text { Aureoboletus } \\
\text { yunnanensis }\end{array}$ & HKAS75050 & - & KT990520 & КT990898 & КT990361 & КT990724 \\
\hline $\begin{array}{l}\text { Aureoboletus } \\
\text { zangii }\end{array}$ & HKAS74751 & - & KT990521 & KT990899 & KT990362 & KT990725 \\
\hline $\begin{array}{l}\text { Aureoboletus } \\
\text { zangii }\end{array}$ & HKAS74766 & - & KT990522 & КT990900 & KT990363 & KT990726 \\
\hline $\begin{array}{l}\text { Baorangia } \\
\text { alexandri }\end{array}$ & $\begin{array}{l}\text { EE 2018a LE } \\
254265\end{array}$ & MH043612 & МH036170 & - & - & - \\
\hline $\begin{array}{l}\text { Baorangia } \\
\text { alexandri }\end{array}$ & $\begin{array}{l}\text { EE 2018a LE } \\
254266\end{array}$ & MH043611 & МH036169 & - & - & - \\
\hline Baorangia bicolor & MB07 001 & - & KF030246 & KF030370 & - & KF030405 \\
\hline $\begin{array}{l}\text { Baorangia } \\
\text { emileorum }\end{array}$ & GS 10213 & MH043613 & MH036171 & - & - & - \\
\hline $\begin{array}{l}\text { Baorangia } \\
\text { emileorum }\end{array}$ & PRM 934960 & MH043616 & МH036174 & - & - & - \\
\hline $\begin{array}{l}\text { Baorangia } \\
\text { emileorum }\end{array}$ & TO HG131114 & МH043617 & MH036175 & - & - & - \\
\hline $\begin{array}{l}\text { Baorangia } \\
\text { emileorum }\end{array}$ & TO HG171015 & MH043615 & MH036173 & - & - & - \\
\hline $\begin{array}{l}\text { Baorangia } \\
\text { emileorum }\end{array}$ & TO HG191015 & MH043614 & MH036172 & - & - & - \\
\hline Baorangia major & OR209 & - & - & - & MG897441 & MG897431 \\
\hline
\end{tabular}


Supplementary Table 1 Continued.

\begin{tabular}{|c|c|c|c|c|c|c|}
\hline \multirow[t]{2}{*}{ Species } & \multirow{2}{*}{$\begin{array}{l}\text { GenBank } \\
\text { voucher }\end{array}$} & \multicolumn{5}{|c|}{ Locus } \\
\hline & & ITS & $28 S$ & RPBI & $R P B 2$ & TEF \\
\hline Baorangia major & OR404 & - & - & - & MG897442 & MG897432 \\
\hline Baorangia major & OR486 & - & - & - & MG897443 & MG897433 \\
\hline $\begin{array}{l}\text { Baorangia } \\
\text { pseudocalopus }\end{array}$ & HKAS75739 & - & KJ184558 & KJ184564 & KM605179 & KJ184570 \\
\hline $\begin{array}{l}\text { Baorangia } \\
\text { rufomaculata }\end{array}$ & ВOTH4414 & - & KF030248 & KF030369 & MG897435 & KF030406 \\
\hline $\begin{array}{l}\text { Boletellus } \\
\text { longicollis }\end{array}$ & HKAS53398 & - & KF112376 & KF112625 & KF112755 & KF112238 \\
\hline $\begin{array}{l}\text { Boletellus } \\
\text { projectellus }\end{array}$ & AFTOL ID 713 & AY789082 & AY684158 & - & AY787218 & AY879116 \\
\hline Boletellus singeri & VB4530 & - & KP327669 & - & - & KP327713 \\
\hline $\begin{array}{l}\text { Boletus } \\
\text { abruptibulbus }\end{array}$ & 4588 & - & KF030302 & KF030388 & - & KF030401 \\
\hline $\begin{array}{l}\text { Boletus aff } \\
\text { amygdalinus }\end{array}$ & HKAS57262 & - & KF112316 & KF112501 & KF112660 & KF112174 \\
\hline $\begin{array}{l}\text { Boletus } \\
\text { albobrunnescens }\end{array}$ & REH8790 & KF668279 & HQ161879 & HQ161877 & - & - \\
\hline $\begin{array}{l}\text { Boletus } \\
\text { amygdalinus }\end{array}$ & $112605 \mathrm{ba}$ & - & JQ326996 & KF030360 & - & JQ327024 \\
\hline $\begin{array}{l}\text { Boletus } \\
\text { austroedulis }\end{array}$ & REH8969 & JN020990 & HQ161847 & HQ161816 & - & - \\
\hline Boletus edulis & BD380 & EU231984 & HQ161848 & HQ161817 & - & - \\
\hline Boletus edulis & $\mathrm{Be} 3$ & - & KF030282 & GU187444 & GU187774 & GU187682 \\
\hline Boletus edulis & HMJAU4637 & - & KF112455 & KF112586 & KF112704 & KF112202 \\
\hline Boletus edulis & $\begin{array}{l}\text { Trudell } 03289 \\
09\end{array}$ & EU231983 & EU232006 & EU231999 & - & - \\
\hline Boletus rubriceps & Arora11331 & КС900403 & КC900404 & - & - & - \\
\hline Boletus rubriceps & $\begin{array}{l}\text { MICH KUO } \\
08150719\end{array}$ & - & MK601722 & - & MK766284 & MK721076 \\
\hline $\begin{array}{l}\text { Boletus } \\
\text { semigastroideus }\end{array}$ & PBM 3076 & JX258840 & KF030352 & KF030384 & - & KF030430 \\
\hline Boletus separans & DPL 2704 & - & KF030329 & KF030385 & - & KF030431 \\
\hline Boletus separans & $\begin{array}{l}\text { MICH KUO } \\
06201002\end{array}$ & - & MK601723 & - & MK766285 & MK721077 \\
\hline $\begin{array}{l}\text { Buchwaldoboletus } \\
\text { lignicola }\end{array}$ & HKAS76674 & - & KF112350 & KF112642 & KF112819 & KF112277 \\
\hline $\begin{array}{l}\text { Buchwaldoboletus } \\
\text { lignicola }\end{array}$ & HKAS84904 & - & KT990538 & - & KT990377 & KT990740 \\
\hline $\begin{array}{l}\text { Buchwaldoboletus } \\
\text { lignicola }\end{array}$ & Pul1 & - & JQ326997 & - & - & JQ327040 \\
\hline $\begin{array}{l}\text { Buchwaldoboletus } \\
\text { lignicola }\end{array}$ & VDKO1140 & - & - & - & MH614756 & MH614710 \\
\hline $\begin{array}{l}\text { Butyriboletus } \\
\text { appendiculatus }\end{array}$ & $\begin{array}{l}\text { BR502008929 } \\
55\end{array}$ & KJ605668 & KJ605677 & KJ619481 & - & - \\
\hline $\begin{array}{l}\text { Butyriboletus } \\
\text { appendiculatus }\end{array}$ & $\begin{array}{l}\text { BR502008933 } \\
90\end{array}$ & KT002598 & КT002609 & KT002621 & - & KT002633 \\
\hline $\begin{array}{l}\text { Butyriboletus } \\
\text { appendiculatus }\end{array}$ & Bap1 & - & AF456837 & KF030359 & - & JQ327025 \\
\hline $\begin{array}{l}\text { Butyriboletus } \\
\text { appendiculatus }\end{array}$ & MB000286 & KT002599 & KT002610 & KT002622 & - & KT002634 \\
\hline $\begin{array}{l}\text { Butyriboletus } \\
\text { brunneus }\end{array}$ & NY00013631 & KT002600 & KT002611 & KT002623 & - & KT002635 \\
\hline $\begin{array}{l}\text { Butyriboletus } \\
\text { pseudoregius }\end{array}$ & $\begin{array}{l}\text { BR502015335 } \\
5951\end{array}$ & KT002603 & KT002614 & KT002626 & - & КT002638 \\
\hline
\end{tabular}


Supplementary Table 1 Continued.

\begin{tabular}{|c|c|c|c|c|c|c|}
\hline \multirow[t]{2}{*}{ Species } & \multirow{2}{*}{$\begin{array}{l}\text { GenBank } \\
\text { voucher }\end{array}$} & \multicolumn{5}{|c|}{ Locus } \\
\hline & & ITS & $28 S$ & $R P B 1$ & RPB2 & TEF \\
\hline $\begin{array}{l}\text { Butyriboletus } \\
\text { pseudoregius }\end{array}$ & $\begin{array}{l}\text { BR502016184 } \\
6502\end{array}$ & KT002602 & KT002613 & KT002625 & - & KT002637 \\
\hline $\begin{array}{l}\text { Butyriboletus } \\
\text { pseudospeciosus }\end{array}$ & HKAS63513 & - & KT990541 & КТ990909 & KT990380 & KT990743 \\
\hline $\begin{array}{l}\text { Butyriboletus } \\
\text { pseudospeciosus }\end{array}$ & HKAS63596 & - & KT990542 & KT990910 & KT990381 & KT990744 \\
\hline $\begin{array}{l}\text { Butyriboletus } \\
\text { pseudospeciosus }\end{array}$ & N K Zeng2127 & MH885349 & MH879687 & - & - & MH879716 \\
\hline $\begin{array}{l}\text { Butyriboletus } \\
\text { regius }\end{array}$ & 11265 & - & KF030267 & - & - & KF030411 \\
\hline $\begin{array}{l}\text { Butyriboletus } \\
\text { regius }\end{array}$ & MB 000287 & KT002605 & KT002616 & KT002628 & - & KT002640 \\
\hline $\begin{array}{l}\text { Butyriboletus } \\
\text { roseoflavus }\end{array}$ & HKAS54099 & KJ909519 & KY418892 & KF739741 & KF739703 & KF739779 \\
\hline $\begin{array}{l}\text { Butyriboletus } \\
\text { roseoflavus }\end{array}$ & HKAS63593 & KJ909517 & KJ184559 & - & - & KJ184571 \\
\hline $\begin{array}{l}\text { Butyriboletus } \\
\text { roseoflavus }\end{array}$ & N K Zeng2123 & MH885348 & MH879686 & - & - & MH885348 \\
\hline $\begin{array}{l}\text { Butyriboletus } \\
\text { subsplendidus }\end{array}$ & HKAS50444 & - & KT990540 & KT990908 & KT990379 & KT990742 \\
\hline $\begin{array}{l}\text { Butyriboletus } \\
\text { yicibus }\end{array}$ & HKAS57503 & KT002608 & KT002620 & KT002632 & - & KT002644 \\
\hline $\begin{array}{l}\text { Butyriboletus } \\
\text { yicibus }\end{array}$ & HKAS68010 & - & KT002619 & KT002631 & - & KT002643 \\
\hline Chalciporus aff & $\begin{array}{l}\text { piperatus } \\
\text { HKAS50214 }\end{array}$ & JQ928610 & JQ928621 & JQ928594 & - & - \\
\hline $\begin{array}{l}\text { Chalciporus } \\
\text { piperatus }\end{array}$ & HKAS84882 & - & КT990562 & - & КТ990397 & КТ990758 \\
\hline $\begin{array}{l}\text { Chalciporus } \\
\text { pseudorubinellus }\end{array}$ & 4302 & - & KF030284 & - & - & KF030441 \\
\hline $\begin{array}{l}\text { Chalciporus } \\
\text { rubinelloides }\end{array}$ & HKAS57362 & - & KT990563 & - & KT990398 & KT990759 \\
\hline $\begin{array}{l}\text { Chalciporus } \\
\text { rubinelloides }\end{array}$ & HKAS58728 & - & KT990564 & - & KT990399 & KT990760 \\
\hline $\begin{array}{l}\text { Chalciporus } \\
\text { rubinelloides }\end{array}$ & HKAS74952 & - & KT990565 & - & KT990400 & KT990761 \\
\hline $\begin{array}{l}\text { Corneroboletus } \\
\text { indecorus }\end{array}$ & OR0863 & - & - & - & MH614772 & MH614726 \\
\hline Cyanoboletus & HKAS76850 & - & KF112343 & KF112527 & KF112697 & KF112187 \\
\hline $\begin{array}{l}\text { Cyanoboletus } \\
\text { brunneoruber }\end{array}$ & HKAS80579 1 & - & KT990568 & KT990926 & KT990401 & - \\
\hline $\begin{array}{l}\text { Cyanoboletus } \\
\text { brunneoruber }\end{array}$ & HKAS80579 2 & - & KT990569 & KT990927 & KT990764 & - \\
\hline $\begin{array}{l}\text { Cyanoboletus } \\
\text { hymenoglutinosus }\end{array}$ & AB 2016 & KT860060 & - & - & - & - \\
\hline $\begin{array}{l}\text { Cyanoboletus } \\
\text { pulverulentus }\end{array}$ & 18188 & JF907794 & - & - & - & - \\
\hline $\begin{array}{l}\text { Cyanoboletus } \\
\text { pulverulentus }\end{array}$ & A21 & JX434686 & - & - & - & - \\
\hline $\begin{array}{l}\text { Cyanoboletus } \\
\text { pulverulentus }\end{array}$ & A7 & JX434685 & - & - & - & - \\
\hline $\begin{array}{l}\text { Cyanoboletus } \\
\text { pulverulentus }\end{array}$ & ASIS22672 & КР004920 & - & - & - & - \\
\hline $\begin{array}{l}\text { Cyanoboletus } \\
\text { pulverulentus }\end{array}$ & $\begin{array}{l}\text { B21 specimen } \\
\text { PRM } 935923\end{array}$ & LT714704 & - & - & - & - \\
\hline
\end{tabular}


Supplementary Table 1 Continued.

\begin{tabular}{|c|c|c|c|c|c|c|}
\hline \multirow[t]{2}{*}{ Species } & \multirow{2}{*}{$\begin{array}{l}\text { GenBank } \\
\text { voucher }\end{array}$} & \multicolumn{5}{|c|}{ Locus } \\
\hline & & ITS & $28 S$ & RPBI & RPB2 & TEF \\
\hline $\begin{array}{l}\text { Cyanoboletus } \\
\text { pulverulentus }\end{array}$ & $\begin{array}{l}\text { B23 specimen } \\
\text { PRM } 944014\end{array}$ & LT714705 & - & - & - & - \\
\hline $\begin{array}{l}\text { Cyanoboletus } \\
\text { pulverulentus }\end{array}$ & $\begin{array}{l}\text { B24 specimen } \\
\text { PRM } 944001\end{array}$ & LT714706 & - & - & - & - \\
\hline $\begin{array}{l}\text { Cyanoboletus } \\
\text { pulverulentus }\end{array}$ & $\begin{array}{l}\text { B25 specimen } \\
\text { PRM } 944013\end{array}$ & LT714707 & - & - & - & - \\
\hline $\begin{array}{l}\text { Cyanoboletus } \\
\text { pulverulentus }\end{array}$ & $\begin{array}{l}\text { B26 specimen } \\
\text { PRM } 944022\end{array}$ & LT714708 & - & - & - & - \\
\hline $\begin{array}{l}\text { Cyanoboletus } \\
\text { pulverulentus }\end{array}$ & $\begin{array}{l}\text { B27 specimen } \\
\text { PRM } 935997\end{array}$ & LT714709 & - & - & - & - \\
\hline $\begin{array}{l}\text { Cyanoboletus } \\
\text { pulverulentus }\end{array}$ & CA05091604 & HM347646 & - & - & - & - \\
\hline $\begin{array}{l}\text { Cyanoboletus } \\
\text { pulverulentus }\end{array}$ & JMP0012 & EU819453 & - & - & - & - \\
\hline $\begin{array}{l}\text { Cyanoboletus } \\
\text { pulverulentus }\end{array}$ & MG 126a & KT157053 & KT157062 & - & - & - \\
\hline $\begin{array}{l}\text { Cyanoboletus } \\
\text { pulverulentus }\end{array}$ & MG 456a & KT157054 & KT157063 & - & - & - \\
\hline $\begin{array}{l}\text { Cyanoboletus } \\
\text { pulverulentus }\end{array}$ & MG 628a & KT157055 & KT157064 & - & KT157069 & - \\
\hline $\begin{array}{l}\text { Cyanoboletus } \\
\text { pulverulentus }\end{array}$ & RT00004 & EU819502 & - & - & - & - \\
\hline $\begin{array}{l}\text { Cyanoboletus } \\
\text { pulverulentus }\end{array}$ & RW109 & - & - & - & KT824013 & - \\
\hline $\begin{array}{l}\text { Cyanoboletus } \\
\text { sinopulverulentus }\end{array}$ & HMAS 266894 & KC579402 & - & - & - & - \\
\hline Cyanoboletus sp & B28 & LT714710 & MF373585 & - & - & - \\
\hline $\begin{array}{l}\text { Cyaonoboletus } \\
\text { instabilis }\end{array}$ & HKAS 59554 & - & KF112412 & KF112528 & KF112698 & KF112186 \\
\hline $\begin{array}{l}\text { Exsudoporus } \\
\text { floridanus }\end{array}$ & $\begin{array}{l}\text { CFMR BZ } \\
3170\end{array}$ & MN250222 & MK601725 & - & MK766287 & MK721079 \\
\hline $\begin{array}{l}\text { Exsudoporus } \\
\text { frostii }\end{array}$ & TENN 067311 & KT002601 & КT002612 & КТ002624 & - & КT002636 \\
\hline $\begin{array}{l}\text { Gymnogaster } \\
\text { boletoides }\end{array}$ & NY01194009 & - & КТ990572 & КТ990928 & KT990406 & КT990768 \\
\hline $\begin{array}{l}\text { Gymnogaster } \\
\text { boletoides }\end{array}$ & REH9455 & - & JX889673 & - & - & JX889683 \\
\hline $\begin{array}{l}\text { Heimioporus } \\
\text { australis }\end{array}$ & REH9288 & - & KP327652 & - & - & KP327703 \\
\hline $\begin{array}{l}\text { Heimioporus } \\
\text { conicus }\end{array}$ & N K Zeng3109 & MH241052 & MH241051 & - & - & MH241053. \\
\hline $\begin{array}{l}\text { Heimioporus } \\
\text { cooloolae }\end{array}$ & REH9817 & - & KP327664 & - & - & KP327710 \\
\hline $\begin{array}{l}\text { Heimioporus } \\
\text { cooloolae }\end{array}$ & REH9852 & - & KP327665 & - & - & KP327711 \\
\hline $\begin{array}{l}\text { Heimioporus } \\
\text { gaojiaocong }\end{array}$ & N K Zeng2788 & - & MF962380 & - & - & MF962410 \\
\hline $\begin{array}{l}\text { Heimioporus } \\
\text { gaojiaocong }\end{array}$ & N K Zeng2791 & MF962398 & MF962383 & - & - & MF962412 \\
\hline $\begin{array}{l}\text { Heimioporus } \\
\text { gaojiaocong }\end{array}$ & N K Zeng2792 & MF962399 & MF962384 & - & - & MF962413 \\
\hline $\begin{array}{l}\text { Heimioporus } \\
\text { gaojiaocong }\end{array}$ & N K Zeng2864 & MF962400 & MF962385 & - & - & MF962415 \\
\hline $\begin{array}{l}\text { Heimioporus } \\
\text { gaojiaocong }\end{array}$ & Z L Yang5901 & MF962394 & MF962377 & - & - & MF962409 \\
\hline
\end{tabular}


Supplementary Table 1 Continued.

\begin{tabular}{|c|c|c|c|c|c|c|}
\hline \multirow[t]{2}{*}{ Species } & \multirow{2}{*}{$\begin{array}{l}\begin{array}{l}\text { GenBank } \\
\text { voucher }\end{array} \\
\end{array}$} & \multicolumn{5}{|c|}{ Locus } \\
\hline & & ITS & $28 S$ & RPBI & $R P B 2$ & TEF \\
\hline $\begin{array}{l}\text { Heimioporus } \\
\text { japonicus }\end{array}$ & HKAS52237 & - & KF112347 & KF112618 & KF112806 & KF112228 \\
\hline $\begin{array}{l}\text { Heimioporus } \\
\text { japonicus }\end{array}$ & $\begin{array}{l}\text { Lancang Y J } \\
\text { Hao84 }\end{array}$ & MF962402 & MF962386 & - & - & MF962416 \\
\hline $\begin{array}{l}\text { Heimioporus } \\
\text { japonicus }\end{array}$ & N K Zeng1335 & MF962404 & MF962388 & - & - & MF962418 \\
\hline $\begin{array}{l}\text { Heimioporus } \\
\text { japonicus }\end{array}$ & N K Zeng1566 & - & MF962389 & - & MF962424 & MF962419 \\
\hline $\begin{array}{l}\text { Heimioporus } \\
\text { japonicus }\end{array}$ & OR114 & - & - & - & KT824004 & KT824037 \\
\hline $\begin{array}{l}\text { Heimioporus } \\
\text { subretisporus }\end{array}$ & HKAS80581 & - & KT990573 & - & KT990407 & KT990769 \\
\hline $\begin{array}{l}\text { Heimioporus } \\
\text { subretisporus }\end{array}$ & HKAS80582 & - & KT990574 & - & KT990409 & KT990770 \\
\hline $\begin{array}{l}\text { Hemileccinum } \\
\text { depilatum }\end{array}$ & AF2845 & - & - & - & MG212633 & MG212591 \\
\hline $\begin{array}{l}\text { Hemileccinum } \\
\text { impolitum }\end{array}$ & Bim1 & - & - & KF030375 & - & JQ327034 \\
\hline $\begin{array}{l}\text { Hemileccinum } \\
\text { impolitum }\end{array}$ & HKAS84869 & - & KT990575 & KT990930 & KT990410 & KT990771 \\
\hline $\begin{array}{l}\text { Hemileccinum } \\
\text { rubropunctum }\end{array}$ & FH MES116 & FJ480434 & - & - & - & - \\
\hline $\begin{array}{l}\text { Hemileccinum } \\
\text { rubropunctum }\end{array}$ & FH MES117 & FJ480433 & - & - & - & - \\
\hline $\begin{array}{l}\text { Hemileccinum } \\
\text { rubropunctum }\end{array}$ & JLF5666 & MH190826 & MK874830 & - & - & - \\
\hline $\begin{array}{l}\text { Hemileccinum } \\
\text { rubropunctum }\end{array}$ & NY01193924 & - & MK601769 & - & MK766328 & MK721123 \\
\hline $\begin{array}{l}\text { Hemileccinum } \\
\text { rubropunctum }\end{array}$ & NY792788 & - & MK601768 & - & MK766327 & MK721122 \\
\hline $\begin{array}{l}\text { Hemileccinum } \\
\text { rugosum }\end{array}$ & HKAS50284 & - & KT990576 & - & KT990411 & KT990772 \\
\hline $\begin{array}{l}\text { Hemileccinum } \\
\text { rugosum }\end{array}$ & HKAS84355 & - & KT990578 & KT990931 & KT990413 & KT990774 \\
\hline $\begin{array}{l}\text { Hemileccinum } \\
\text { rugosum }\end{array}$ & HKAS84970 & - & KT990577 & - & KT990412 & KT990773 \\
\hline $\begin{array}{l}\text { Hemileccinum } \\
\text { subglabripes }\end{array}$ & $\begin{array}{l}\text { MICH KUO } \\
07070702\end{array}$ & - & MK601737 & - & MK766299 & MK721091 \\
\hline $\begin{array}{l}\text { Hemileccinum } \\
\text { subglabripes }\end{array}$ & $\begin{array}{l}\text { MICH KUO } \\
07230802\end{array}$ & - & MK601738 & - & MK766300 & MK721092 \\
\hline $\begin{array}{l}\text { Hemileccinum } \\
\text { subglabripes }\end{array}$ & $\begin{array}{l}\text { MICH KUO } \\
08301402\end{array}$ & - & MK601739 & - & MK766301 & MK721093 \\
\hline $\begin{array}{l}\text { Hemileccinum } \\
\text { subglabripes }\end{array}$ & MO 294169 & MN128237 & MN128238 & - & - & - \\
\hline $\begin{array}{l}\text { Hemileccinum } \\
\text { subglabripum }\end{array}$ & 72206 & - & KF030303 & KF030374 & - & KF030404 \\
\hline $\begin{array}{l}\text { Hortiboletus aff } \\
\text { rubellus }\end{array}$ & HKAS51239 & - & KF112425 & KF112618 & KF112695 & KF112184 \\
\hline $\begin{array}{l}\text { Hortiboletus } \\
\text { amygdalinus }\end{array}$ & HKAS54166 & - & KT990581 & КT990933 & KT990416 & КТ990777 \\
\hline $\begin{array}{l}\text { Hortiboletus } \\
\text { amygdalinus }\end{array}$ & HKAS54242 & - & KT990580 & - & KT990415 & КТ990776 \\
\hline $\begin{array}{l}\text { Hortiboletus } \\
\text { campestris }\end{array}$ & $\begin{array}{l}\text { MICH KUO } \\
08240502\end{array}$ & - & MK601740 & - & MK766302 & MK721094 \\
\hline
\end{tabular}


Supplementary Table 1 Continued.

\begin{tabular}{|c|c|c|c|c|c|c|}
\hline \multirow[t]{2}{*}{ Species } & \multirow{2}{*}{$\begin{array}{l}\text { GenBank } \\
\text { voucher }\end{array}$} & \multicolumn{5}{|c|}{ Locus } \\
\hline & & ITS & $28 S$ & RPBI & $R P B 2$ & TEF \\
\hline $\begin{array}{l}\text { Hortiboletus cf } \\
\text { rubellus }\end{array}$ & $\begin{array}{l}\text { East Coast } \\
\text { MB03 } 033\end{array}$ & - & - & KF030371 & - & KF030419 \\
\hline $\begin{array}{l}\text { Hortiboletus cf } \\
\text { rubellus }\end{array}$ & $\begin{array}{l}\text { West Coast } \\
\text { PBM } 1331\end{array}$ & - & - & - & - & KF030420 \\
\hline $\begin{array}{l}\text { Hortiboletus } \\
\text { indorubellus }\end{array}$ & DC 14 & KT319647 & KU566807 & - & - & - \\
\hline $\begin{array}{l}\text { Hortiboletus } \\
\text { indorubellus }\end{array}$ & LS15 & MK002767 & MK002872 & - & - & - \\
\hline $\begin{array}{l}\text { Hortiboletus } \\
\text { rubellus }\end{array}$ & $\begin{array}{l}\text { MICH KUO } \\
06081002\end{array}$ & - & MK601741 & - & MK766303 & MK721095 \\
\hline $\begin{array}{l}\text { Hortiboletus } \\
\text { rubellus }\end{array}$ & VDKO0403 & - & - & - & MH614774 & - \\
\hline $\begin{array}{l}\text { Hortiboletus } \\
\text { subpaludosus }\end{array}$ & HKAS52659 & - & КТ990582 & - & КT990417 & KT990778 \\
\hline $\begin{array}{l}\text { Hortiboletus } \\
\text { subpaludosus }\end{array}$ & HKAS68158 & - & KT990583 & KT990934 & KT990418 & KT990779 \\
\hline $\begin{array}{l}\text { Hymenogaster } \\
\text { behrii }\end{array}$ & $\begin{array}{l}\text { OSC } \\
\text { Trappe12988 }\end{array}$ & KJ882288 & - & - & - & - \\
\hline $\begin{array}{l}\text { Hymenogaster } \\
\text { behrii }\end{array}$ & $\begin{array}{l}\text { OSC } \\
\text { Trappe17620 }\end{array}$ & KJ882290 & - & - & - & - \\
\hline $\begin{array}{l}\text { Hymenogaster } \\
\text { macmurphyi }\end{array}$ & OSC MES282b & KJ882289 & KJ882291 & - & - & - \\
\hline $\begin{array}{l}\text { Lanmaoa } \\
\text { angustispora }\end{array}$ & HKAS74752 & - & KM605139 & KM605166 & KM605177 & KM605154 \\
\hline $\begin{array}{l}\text { Lanmaoa } \\
\text { angustispora }\end{array}$ & HKAS74759 & - & KM605140 & KM605167 & KM605178 & KM605155 \\
\hline Lanmaoa asiatica & HKAS54095 & - & KM605141 & KM605164 & KM605174 & KM605151 \\
\hline Lanmaoa asiatica & HKAS63516 & - & КT990584 & КТ990935 & КТ990419 & KT990780 \\
\hline Lanmaoa asiatica & HKAS63592 & - & KM605142 & KM605163 & KM605175 & KM605152 \\
\hline Lanmaoa asiatica & HKAS63603 & - & KM605143 & KM605165 & KM605176 & KM605153 \\
\hline Lanmaoa asiatica & N K Zeng2125 & MG030477 & MG030470 & - & - & MG030481 \\
\hline Lanmaoa asiatica & N K Zeng2795 & - & MG030469 & - & - & MG030480 \\
\hline Lanmaoa asiatica & OR0228 & - & - & - & MH614777 & MH614730 \\
\hline Lanmaoa borealis & 2858 & - & JQ326998 & - & - & JQ327021 \\
\hline $\begin{array}{l}\text { Lanmaoa } \\
\text { carminipes }\end{array}$ & MB06 061 & - & JQ327001 & KF030363 & - & JQ327022 \\
\hline Lanmaoa cf & borealis AB35 & MH796994 & - & - & - & - \\
\hline $\begin{array}{l}\text { Lanmaoa } \\
\text { flavorubra }\end{array}$ & NY775777 & - & JQ924339 & - & KF112681 & KF112160 \\
\hline $\begin{array}{l}\text { Lanmaoa } \\
\text { macrocarpa }\end{array}$ & N K Zeng3021 & - & - & - & - & MH879713 \\
\hline $\begin{array}{l}\text { Lanmaoa } \\
\text { macrocarpa }\end{array}$ & N K Zeng3251 & MH885347 & MH879685 & - & - & MH885347 \\
\hline $\begin{array}{l}\text { Lanmaoa } \\
\text { pallidorosea }\end{array}$ & BOTH4432 & - & - & - & MG897437 & MG897427 \\
\hline $\begin{array}{l}\text { Lanmaoa } \\
\text { pallidorosea }\end{array}$ & MO 210760 & - & MH216001 & - & - & MH318610 \\
\hline $\begin{array}{l}\text { Lanmaoa } \\
\text { pallidorosea }\end{array}$ & MO 247881 & MH234471 & MH230088 & - & - & MH337278 \\
\hline $\begin{array}{l}\text { Lanmaoa } \\
\text { pseudosensibilis }\end{array}$ & DS615 07 & - & KF030257 & - & - & KF030407 \\
\hline $\begin{array}{l}\text { Lanmaoa } \\
\text { roseocrispans }\end{array}$ & HOLOTYPE & - & MH036169 & - & - & KP327616 \\
\hline $\begin{array}{l}\text { Lanmaoa } \\
\text { rubriceps }\end{array}$ & N K Zeng2773 & MG030475 & MG030468 & - & - & MG030479 \\
\hline
\end{tabular}


Supplementary Table 1 Continued.

\begin{tabular}{|c|c|c|c|c|c|c|}
\hline \multirow[t]{2}{*}{ Species } & \multirow{2}{*}{$\begin{array}{l}\text { GenBank } \\
\text { voucher }\end{array}$} & \multicolumn{5}{|c|}{ Locus } \\
\hline & & ITS & $28 S$ & RPBI & $R P B 2$ & TEF \\
\hline $\begin{array}{l}\text { Lanmaoa } \\
\text { rubriceps }\end{array}$ & N K Zeng3006 & MH885346 & MH879683 & - & - & MH879712 \\
\hline $\begin{array}{l}\text { Nigroboletus } \\
\text { roseonigrescens }\end{array}$ & GDGM 43238 & KT220584 & KT220588 & KT220591 & - & KT220588 \\
\hline $\begin{array}{l}\text { Nigroboletus } \\
\text { roseonigrescens }\end{array}$ & MG 524a & KT220586 & KT220590 & KT220593 & - & - \\
\hline $\begin{array}{l}\text { Nigroboletus } \\
\text { roseonigrescens }\end{array}$ & ZT 13553 & KT220585 & KT220589 & KT220592 & KT220594 & KT220596 \\
\hline $\begin{array}{l}\text { Pulchroboletus } \\
\text { roseoalbidus }\end{array}$ & AMB 12757 & KJ729486 & NG_060126 & - & - & KJ729512 \\
\hline $\begin{array}{l}\text { Pulchroboletus } \\
\text { roseoalbidus }\end{array}$ & MCVE 17577 & KJ729490 & KJ729503 & - & - & - \\
\hline $\begin{array}{l}\text { Pulchroboletus } \\
\text { roseoalbidus }\end{array}$ & MCVE 18217 & KJ729488 & KJ729501 & - & - & - \\
\hline $\begin{array}{l}\text { Pulchroboletus } \\
\text { roseoalbidus }\end{array}$ & MG416a & KJ729489 & KJ729502 & - & - & - \\
\hline $\begin{array}{l}\text { Pulchroboletus } \\
\text { roseoalbidus }\end{array}$ & MG532a & KJ729487 & KJ729500 & - & - & - \\
\hline $\begin{array}{l}\text { Pulchroboletus } \\
\text { sclerotiorum }\end{array}$ & FLAS F 60333 & MF098659 & MF614166 & MF614168 & MF614169 & MF614167 \\
\hline $\begin{array}{l}\text { Pulchroboletus } \\
\text { sclerotiorum }\end{array}$ & FLAS F 60334 & MF098660 & - & - & MF614164 & MF614165 \\
\hline $\begin{array}{l}\text { Pulchroboletus } \\
\text { sclerotiorum }\end{array}$ & MO 243879 & - & MH257545 & - & - & MH337281 \\
\hline $\begin{array}{l}\text { Pulveroboletus } \\
\text { auriporus }\end{array}$ & DD971 & - & AY612819 & - & - & - \\
\hline $\begin{array}{l}\text { Sinoboletus } \\
\text { duplicatoporus }\end{array}$ & HKAS50498 & - & KF112361 & KF112561 & KF112754 & KF112230 \\
\hline $\begin{array}{l}\text { Suillellus } \\
\text { amygdalinus }\end{array}$ & NY00035656 & - & KT990650 & KT990990 & KT990477 & KT990840 \\
\hline $\begin{array}{l}\text { Suillellus } \\
\text { amygdalinus }\end{array}$ & NY00815464 & - & KT990659 & KT990997 & KT990484 & KT990848 \\
\hline Suillellus queletii & VDKO1185 & - & - & - & MH645604 & MH645598 \\
\hline $\begin{array}{l}\text { Suillellus } \\
\text { subamygdalinus }\end{array}$ & HKAS53641 & - & KT990651 & КT990991 & KT990478 & KT990841 \\
\hline $\begin{array}{l}\text { Suillellus } \\
\text { subamygdalinus }\end{array}$ & HKAS57953 & - & KT990652 & KT990992 & - & KT990842 \\
\hline $\begin{array}{l}\text { Suillellus } \\
\text { subamygdalinus }\end{array}$ & HKAS74745 & - & KT990653 & KT990993 & KT990479 & KT990843 \\
\hline $\begin{array}{l}\text { Xerocomellus } \\
\text { armeniacus }\end{array}$ & $\begin{array}{l}\text { MA Fungi } \\
47678\end{array}$ & AJ419221 & - & - & - & - \\
\hline $\begin{array}{l}\text { Xerocomellus } \\
\text { armeniacus }\end{array}$ & CM058 & KP826760 & - & - & - & - \\
\hline $\begin{array}{l}\text { Xerocomellus } \\
\text { armeniacus }\end{array}$ & ML41842RP & MH011927 & - & - & - & - \\
\hline $\begin{array}{l}\text { "Rheubarbaribolet } \\
\text { us" persicolor }\end{array}$ & 17602 & JF908795 & - & - & - & - \\
\hline $\begin{array}{l}\text { "Rheubarbaribolet } \\
\text { us" persicolor }\end{array}$ & SOMF 29860 & MH011931 & - & - & - & - \\
\hline $\begin{array}{l}\text { "Rheubarbaribolet } \\
\text { us" persicolor }\end{array}$ & SOMF 298154 & MH011932 & - & - & - & - \\
\hline $\begin{array}{l}\text { Xerocomellus } \\
\text { chrysenteron }\end{array}$ & HKAS56494 & - & KF112357 & KF112526 & KF112685 & KF112172 \\
\hline $\begin{array}{l}\text { Xerocomellus } \\
\text { chrysenteron }\end{array}$ & $\begin{array}{l}\text { MICH KUO } \\
07271202\end{array}$ & - & - & - & MK766373 & MK721171 \\
\hline
\end{tabular}


Supplementary Table 1 Continued.

\begin{tabular}{|c|c|c|c|c|c|c|}
\hline \multirow[t]{2}{*}{ Species } & \multirow{2}{*}{$\begin{array}{l}\text { GenBank } \\
\text { voucher }\end{array}$} & \multicolumn{5}{|c|}{ Locus } \\
\hline & & ITS & $28 S$ & RPBI & RPB2 & TEF \\
\hline $\begin{array}{l}\text { Xerocomellus } \\
\text { chrysenteron }\end{array}$ & $\begin{array}{l}\text { MICH KUO } \\
09260903\end{array}$ & - & - & - & MK766374 & MK721172 \\
\hline $\begin{array}{l}\text { Xerocomellus } \\
\text { chrysenteron }\end{array}$ & VDKO0821 & - & - & - & KT824017 & KT824050 \\
\hline $\begin{array}{l}\text { Xerocomellus } \\
\text { chrysenteron }\end{array}$ & Xch1 & - & - & KF030365 & - & KF030415 \\
\hline $\begin{array}{l}\text { Xerocomellus } \\
\text { cisalpinus }\end{array}$ & ADK4864 & - & - & - & KT823993 & KT824026 \\
\hline $\begin{array}{l}\text { Xerocomellus } \\
\text { cisalpinus }\end{array}$ & AT2005034 & - & - & KF030367 & - & KF030417 \\
\hline $\begin{array}{l}\text { Xerocomellus } \\
\text { cisalpinus }\end{array}$ & PDD94421 & - & JQ924322 & KF112525 & KF112686 & KF112171 \\
\hline $\begin{array}{l}\text { Xerocomellus } \\
\text { communis }\end{array}$ & HKAS50467 & - & KT990670 & KT991008 & KT990494 & KT990858 \\
\hline $\begin{array}{l}\text { Xerocomellus } \\
\text { communis }\end{array}$ & HKAS68204 & - & - & KT991009 & KT990495 & KT991009 \\
\hline $\begin{array}{l}\text { Xerocomellus } \\
\text { corneri }\end{array}$ & HKAS52503 & - & KT990668 & KT991006 & KT990492 & KT990856 \\
\hline $\begin{array}{l}\text { Xerocomellus } \\
\text { corneri }\end{array}$ & HKAS90206 & - & KT990669 & KT991007 & KT990493 & KT990857 \\
\hline $\begin{array}{l}\text { Xerocomellus } \\
\text { porosporus }\end{array}$ & VDKO0311 & - & - & - & MH614773 & MH614727 \\
\hline $\begin{array}{l}\text { Xerocomellus } \\
\text { ripariellus }\end{array}$ & VDKO0404 & - & - & - & MH614793 & MH614746 \\
\hline Xerocomellus sp & HKAS50466 & - & KF112372 & KF112549 & KT990494 & KF112183 \\
\hline Xerocomellus sp & HKAS50467 & - & KF112489 & KT991008 & KF112770 & KF112173 \\
\hline Xerocomellus sp & HKAS51292 & - & KF112369 & KF112547 & KF112692 & KF112181 \\
\hline Xerocomellus sp & HKAS56311 & - & KF112340 & KF112524 & KF112684 & KF112170 \\
\hline Xerocomellus sp & HKAS59608 & - & KF112371 & KF112551 & KF112696 & KF112185 \\
\hline Xerocomellus $s p$ & HKAS76673 & - & KF112370 & KF112548 & KF112693 & KF112182 \\
\hline $\begin{array}{l}\text { Xerocomellus } \\
\text { zelleri }\end{array}$ & JLF2977 & KM213666 & KU144799 & - & - & - \\
\hline $\begin{array}{l}\text { Xerocomellus } \\
\text { zelleri }\end{array}$ & REH8724 & - & KF030271 & KF030366 & - & KF030416 \\
\hline $\begin{array}{l}\text { Xerocomus } \\
\text { hortonii }\end{array}$ & $\begin{array}{l}\text { MICH-KUO } \\
07050706\end{array}$ & - & MK601821 & - & MK766377 & MK721175 \\
\hline $\begin{array}{l}\text { Xerocomellus } \\
\text { armeniacus }\end{array}$ & $\begin{array}{l}\text { MA-Fungi } \\
47678\end{array}$ & AJ419221 & - & - & - & - \\
\hline $\begin{array}{l}\text { Xerocomellus } \\
\text { persicolor }\end{array}$ & ML41842RP & MH011927 & - & - & - & - \\
\hline $\begin{array}{l}\text { Boletus } \\
\text { pakistanicus }\end{array}$ & & JQ178324 & - & - & - & - \\
\hline Bovista himalaica & & JN411938 & - & - & - & - \\
\hline Xerocomellus & 17602 & JF908795 & - & - & - & - \\
\hline Xerocomellus & SOMF12854 & MH011931 & - & - & - & - \\
\hline Xerocomellus & SOMF29860 & MH011932 & - & - & - & - \\
\hline Xerocomellus & CM058 & KP823760 & - & - & - & - \\
\hline $\begin{array}{l}\text { Aureoboletus } \\
\text { pseudoauriporus }\end{array}$ & Farid 501 & MW675741 & MW662576 & MW737500 & MW737463 & - \\
\hline $\begin{array}{l}\text { Aureoboletus } \\
\text { pseudoauriporus }\end{array}$ & JAB 124 & MW675754 & - & - & - & - \\
\hline $\begin{array}{l}\text { Aureoboletus } \\
\text { pseudoauriporus }\end{array}$ & JAB 130 & MW675725 & MW662581 & - & - & - \\
\hline $\begin{array}{l}\text { Aureoboletus } \\
\text { pseudoauriporus }\end{array}$ & JAB 320 & MW675726 & MW662585 & MW737508 & MW737468 & MW737489 \\
\hline
\end{tabular}


Supplementary Table 1 Continued.

\begin{tabular}{|c|c|c|c|c|c|c|}
\hline \multirow[t]{2}{*}{ Species } & \multirow{2}{*}{$\begin{array}{l}\text { GenBank } \\
\text { voucher }\end{array}$} & \multicolumn{5}{|c|}{ Locus } \\
\hline & & ITS & $28 S$ & RPB1 & RPB2 & TEF \\
\hline $\begin{array}{l}\text { Aureoboletus } \\
\text { pseudoauriporus }\end{array}$ & JAB 80 & MW675723 & MW662588 & MW737510 & MW737471 & MW737490 \\
\hline $\begin{array}{l}\text { Cyanoboletus } \\
\text { bessettei }\end{array}$ & ARB 1393A & MW675734 & MW662571 & - & MW737457 & MW737482 \\
\hline $\begin{array}{l}\text { Cyanoboletus } \\
\text { bessettei }\end{array}$ & ARB 1393B & MW675735 & - & - & MW737458 & MW737483 \\
\hline $\begin{array}{l}\text { Cyanoboletus } \\
\text { cyaneitinctus }\end{array}$ & JAB 324 & MW675732 & MW662586 & MW737505 & MW737469 & - \\
\hline $\begin{array}{l}\text { Cyanoboletus } \\
\text { cyaneitinctus }\end{array}$ & JAB 325 & MW675733 & - & MW737506 & MW737470 & - \\
\hline $\begin{array}{l}\text { Cyanoboletus } \\
\text { cyaneitinctus }\end{array}$ & Farid 340 & MW675739 & MW662574 & MW737502 & MW737461 & - \\
\hline $\begin{array}{l}\text { Cyanoboletus } \\
\text { cyaneitinctus }\end{array}$ & Farid 920 & MW675744 & MW662579 & MW737503 & MW737465 & - \\
\hline $\begin{array}{l}\text { Cyanoboletus } \\
\text { cyaneitinctus }\end{array}$ & JAB 184 & MW675731 & MW662584 & MW737504 & MW737467 & - \\
\hline $\begin{array}{l}\text { Cyanoboletus } \\
\text { cyaneitinctus } \\
\text { f. reticulatus }\end{array}$ & Farid 1035 & MZ746113 & - & - & - & - \\
\hline $\begin{array}{l}\text { Exsudoporus } \\
\text { floridanus }\end{array}$ & Farid 499 & - & - & MW737497 & MW737459 & MW737484 \\
\hline $\begin{array}{l}\text { Hemileccinum } \\
\text { floridanum }\end{array}$ & AB16 & MW675745 & MW662570 & - & - & MW737481 \\
\hline $\begin{array}{l}\text { Hemileccinum } \\
\text { floridanum }\end{array}$ & Farid 1032 & MW675746 & MW662573 & - & - & - \\
\hline $\begin{array}{l}\text { Hemileccinum } \\
\text { floridanum }\end{array}$ & Farid 625 & MW675742 & MW662577 & - & - & - \\
\hline $\begin{array}{l}\text { Hemileccinum } \\
\text { floridanum }\end{array}$ & JAB 142 & MW675730 & MW662583 & - & - & MW737488 \\
\hline $\begin{array}{l}\text { Lanmaoa } \\
\text { sublurida }\end{array}$ & Farid 1023 & MW675736 & MW662572 & MW737498 & MW737460 & MW737485 \\
\hline $\begin{array}{l}\text { Lanmaoa } \\
\text { sublurida }\end{array}$ & Farid 343 & MW675740 & MW662575 & MW737499 & MW737462 & MW737486 \\
\hline $\begin{array}{l}\text { Lanmaoa } \\
\text { sublurida }\end{array}$ & Farid 631 & MW675743 & MW662578 & MW737501 & MW737464 & MW737487 \\
\hline $\begin{array}{l}\text { Pulchroboletus } \\
\text { rubricitrinus }\end{array}$ & Farid 335 & MF193884 & MG026638 & MW737512 & MW737466 & - \\
\hline $\begin{array}{l}\text { Xerocomellus } \\
\text { bolinii }\end{array}$ & JAB 110 & MW675728 & MW662580 & MW737507 & - & - \\
\hline $\begin{array}{l}\text { Xerocomellus } \\
\text { bolinii }\end{array}$ & JAB 43 & MW675734 & MW662587 & MW737509 & - & - \\
\hline $\begin{array}{l}\text { Xerocomellus } \\
\text { bolinii }\end{array}$ & JAB 133 & MW675729 & MW662582 & - & - & - \\
\hline $\begin{array}{l}\text { Xerocomellus } \\
\text { bolinii }\end{array}$ & JAB 95 & MW675735 & MW662589 & MW737511 & MW737472 & MW737491 \\
\hline $\begin{array}{l}\text { Xerocomellus } \\
\text { salicicola }\end{array}$ & B391 & MK552408 & MW662569 & MW737496 & - & - \\
\hline $\begin{array}{l}\text { Hortiboletus } \\
\text { coccyginus }\end{array}$ & JLF 3093 & KU144805 & - & MW737513 & MW737473 & - \\
\hline $\begin{array}{l}\text { Xerocomellus } \\
\text { amylosporus }\end{array}$ & JLF 3498 & KU144743 & - & MW737514 & MW737474 & MW737492 \\
\hline $\begin{array}{l}\text { Xerocomellus } \\
\text { rainisiae }\end{array}$ & JLF 3523 & KU144789 & KU144790 & MW737515 & MW737475 & - \\
\hline Xerocomellus & JLF 3558 & KU144785 & KU144786 & MW737516 & MW737476 & - \\
\hline
\end{tabular}


Supplementary Table 1 Continued.

\begin{tabular}{|c|c|c|c|c|c|c|}
\hline \multirow{2}{*}{ Species } & \multirow{2}{*}{$\begin{array}{l}\text { GenBank } \\
\text { voucher }\end{array}$} & \multicolumn{5}{|c|}{ Locus } \\
\hline & & ITS & $28 S$ & RPBI & RPB2 & TEF \\
\hline $\begin{array}{l}\text { Xerocomellus } \\
\text { atropurpureus }\end{array}$ & JLF 3620 & KU144749 & KU144750 & MW737517 & MW737477 & MW737495 \\
\hline $\begin{array}{l}\text { Xerocomellus } \\
\text { dryophilus }\end{array}$ & JLF 4134 & KX534076 & KY659593 & - & MW737478 & MW737493 \\
\hline $\begin{array}{l}\text { Xerocomellus } \\
\text { dryophilus }\end{array}$ & JLF 4791 & - & - & - & MW737479 & MW737494 \\
\hline $\begin{array}{l}\text { Xerocomellus } \\
\text { mendocinensis }\end{array}$ & JLF 5684 & MH168533 & MN294419 & MW737518 & MW737480 & - \\
\hline $\begin{array}{l}\text { Xerocomellus } \\
\text { diffractus }\end{array}$ & JLF 5745 & MH168534 & - & MW737519 & - & - \\
\hline
\end{tabular}

